\title{
Reviews and syntheses: Biological weathering and its consequences at different spatial levels - from nanoscale to global scale
}

\author{
Roger D. Finlay ${ }^{1}$, Shahid Mahmood ${ }^{1}$, Nicholas Rosenstock ${ }^{2}$, Emile B. Bolou-Bi ${ }^{3}$, Stephan J. Köhler ${ }^{4}$, \\ Zaenab Fahad ${ }^{1,5}$, Anna Rosling ${ }^{5}$, Håkan Wallander ${ }^{2}$, Salim Belyazid ${ }^{6}$, Kevin Bishop ${ }^{4}$, and Bin Lian ${ }^{7}$ \\ ${ }^{1}$ Uppsala BioCenter, Department of Forest Mycology and Plant Pathology, Swedish University of Agricultural Sciences, \\ 75007 Uppsala, Sweden \\ ${ }^{2}$ Department of Biology, Lund University, Box 117, 22100 Lund, Sweden \\ ${ }^{3}$ Université Felix Houphouët-Boigny, UFR des Sciences de la Terre et des Ressources Minières, \\ Departement des Sciences du sol, BP 582 Abidjan 22, Côte D’Ivoire \\ ${ }^{4}$ Soil-Water-Environment Center, Department of Aquatic Sciences and Assessment, Swedish University of Agricultural \\ Sciences, 75007 Uppsala, Sweden \\ ${ }^{5}$ Department of Ecology and Genetics, EBC, Uppsala University 75236 Uppsala, Sweden \\ ${ }^{6}$ Department of Physical Geography, Stockholm University, 10691 Stockholm, Sweden \\ ${ }^{7}$ College of Marine Sciences and Engineering, Nanjing Normal University, Nanjing 210023, China
}

Correspondence: Roger D. Finlay (roger.finlay@slu.se)

Received: 9 February 2019 - Discussion started: 18 February 2019

Revised: 16 February 2020 - Accepted: 20 February 2020 - Published: 25 March 2020

\begin{abstract}
Plant nutrients can be recycled through microbial decomposition of organic matter but replacement of base cations and phosphorus, lost through harvesting of biomass/biofuels or leaching, requires de novo supply of fresh nutrients released through weathering of soil parent material (minerals and rocks). Weathering involves physical and chemical processes that are modified by biological activity of plants, microorganisms and animals. This article reviews recent progress made in understanding biological processes contributing to weathering. A perspective of increasing spatial scale is adopted, examining the consequences of biological activity for weathering from nanoscale interactions, through in vitro and in planta microcosm and mesocosm studies, to field experiments, and finally ecosystem and global level effects. The topics discussed include the physical alteration of minerals and mineral surfaces; the composition, amounts, chemical properties, and effects of plant and microbial secretions; and the role of carbon flow (including stabilisation and sequestration of $\mathrm{C}$ in organic and inorganic forms). Although the predominant focus is on the effects of fungi in forest ecosystems, the properties of biofilms, including bacterial interactions, are also discussed. The implications of these biological processes for modelling are
\end{abstract}

discussed, and we attempt to identify some key questions and knowledge gaps, as well as experimental approaches and areas of research in which future studies are likely to yield useful results. A particular focus of this article is to improve the representation of the ways in which biological processes complement physical and chemical processes that mobilise mineral elements, making them available for plant uptake. This is necessary to produce better estimates of weathering that are required for sustainable management of forests in a post-fossil-fuel economy. While there are abundant examples of nanometre- and micrometre-scale physical interactions between microorganisms and different minerals, opinion appears to be divided with respect to the quantitative significance of these observations for overall weathering. Numerous in vitro experiments and microcosm studies involving plants and their associated microorganisms suggest that the allocation of plant-derived carbon, mineral dissolution and plant nutrient status are tightly coupled, but there is still disagreement about the extent to which these processes contribute to field-scale observations. Apart from providing dynamically responsive pathways for the allocation of plant-derived carbon to power dissolution of minerals, mycorrhizal mycelia provide conduits for the long-distance trans- 
portation of weathering products back to plants that are also quantitatively significant sinks for released nutrients. These mycelial pathways bridge heterogeneous substrates, reducing the influence of local variation in $\mathrm{C}: \mathrm{N}$ ratios. The production of polysaccharide matrices by biofilms of interacting bacteria and/or fungi at interfaces with mineral surfaces and roots influences patterns of production of antibiotics and quorum sensing molecules, with concomitant effects on microbial community structure, and the qualitative and quantitative composition of mineral-solubilising compounds and weathering products. Patterns of carbon allocation and nutrient mobilisation from both organic and inorganic substrates have been studied at larger spatial and temporal scales, including both ecosystem and global levels, and there is a generally wider degree of acceptance of the "systemic" effects of microorganisms on patterns of nutrient mobilisation. Theories about the evolutionary development of weathering processes have been advanced but there is still a lack of information connecting processes at different spatial scales. Detailed studies of the liquid chemistry of local weathering sites at the micrometre scale, together with upscaling to soil-scale dissolution rates, are advocated, as well as new approaches involving stable isotopes.

\section{Introduction}

Modelling of base cation supply using the PROFILE/ForSAFE modelling platform (Kronnäs et al., 2019) suggests that planned intensification of Swedish forestry, involving increased harvesting of organic residues for biofuel, will not be sustainable in the long term without compensatory measures such as wood ash recycling (Akselsson et al., 2007; Klaminder et al., 2011; Futter et al., 2012; Moldan et al., 2017). The base cations and phosphorus that are essential for forest growth can be recycled from organic residues through microbial decomposition. However, if they are lost through removal of organic material, the only way they can be replaced is by weathering of rocks and minerals, or deposition from the atmosphere. There is a need to improve the available estimates of weathering and to improve our knowledge of the ways in which biological processes may complement physical and chemical processes that mobilise mineral elements, making them available for plant uptake.

The role of fungi in biological weathering in boreal forest soils was reviewed by Hoffland et al. (2004) and by Finlay et al. (2009). More recent reviews of the more specific roles of mycorrhizal symbiosis in mineral weathering and nutrient mining from soil parent material (Smits and Wallander, 2017), pedogenesis (Leake and Read, 2017) and immobilisation of carbon in mycorrhizal mycelial biomass and secretions (Finlay and Clemmensen, 2017) have also been published. Twelve testable hypotheses on the geobiology of weathering were outlined by Brantley et al. (2011). These authors concede that some of the outlined hypotheses have been implicit in scientific research conducted since the late 1800s but argue that there are now new analytical, modelling and field opportunities to test these hypotheses. The aim of the present article is to review recent advances in the understanding of biological weathering, particularly with respect to nutrient and carbon cycling within boreal forests, including findings made within the interdisciplinary project Quantifying Weathering Rates for Sustainable Forestry (QWARTS, 2012-2016). One major motivation for this study was the concern that the modelling tools used to determine the longterm supply of weathering products for sustainable forest growth may have been missing biological processes that allow a forest ecosystem to alter the rate of weathering in response to the biological demand for these weathering products (Klaminder et al., 2011).

Biological weathering involves the weakening and disintegration of rocks and dissolution of minerals, caused by the activity of plants, animals and microorganisms. Biological weathering takes place in conjunction with physical and chemical processes, but there is still disagreement about the quantitative contribution of biogenic weathering to overall weathering (see Leake and Read, 2017; Smits and Wallander, 2017). The first of the 12 hypotheses of Brantley et al. (2011) is that "Solar-to-chemical conversion of energy by plants regulates flows of carbon, water, and nutrients through plant-microbe soil networks, thereby controlling the location and extent of biological weathering". The supply and transport of photosynthetically derived carbon through roots and mycorrhizal hyphae to organic and inorganic substrates is a fundamental biogeochemical process (Jones et al., 2009), influencing both decomposition and mineral weathering, and these two processes influence each other. This flow of carbon and the role of plant-microbe-soil interactions in the rhizosphere have been reviewed from an evolutionary perspective (Lambers et al., 2009) and with respect to their potential applications in sustainable agriculture, nature conservation, the development of bioenergy crops and the mitigation of climate change (Philippot et al., 2013). Since there is disagreement about whether biological processes demonstrated at small spatial scales contribute significantly to fieldscale processes but a greater degree of consensus about the importance of systemic effects of biological weathering at larger spatial and temporal scales, we have adopted a spatial perspective. We start by reviewing processes occurring at the nanometre and micrometre scale before discussing in vitro microcosm experiments, mesocosm studies with plants, field experiments, and finally studies of effects at the ecosystem and global scale. Biological weathering is also discussed from an evolutionary perspective, and some recent experiments using stable isotopes are presented. Each section is followed by a short summary in which we attempt to list the main conclusions and some of the remaining questions and knowledge gaps. Finally, different modelling approaches are 
discussed in relation to how we can incorporate the biological features discussed earlier and improve the reliability of models.

\section{Microscale-nanoscale observations of physical alteration of minerals}

The idea that microorganisms may alter rocks and minerals is not new, and biogenic etching of microfractures in borosilicate glass and crystalline silicates (olivine) by microfungi (Penicillium notatum and Aspergillus amstelodami), presumed to be producing both organic acids and siderophores, was demonstrated by Callot et al. (1987). Early studies by Paris et al. $(1995,1996)$ demonstrated in vitro weathering of phlogopite involving displacement of non-exchangeable interlayer $\mathrm{K}^{+}$and alteration of the crystal lattice structure, as well as stimulated accumulation of oxalate under simultaneous $\mathrm{K}^{+}$and $\mathrm{Mg}^{2+}$ deficiency. The widespread occurrence of tubular pores, 3-10 $\mu \mathrm{m}$ in diameter, has been demonstrated in weatherable minerals in podzol surface soils and shallow granitic rock under European coniferous forests (van Breemen et al., 2000; Jongmans et al., 1997; Landeweert et al., 2001). Some of these pores were found to be occupied by fungal hyphae, and the authors speculated that they could be formed by the weathering action of hyphae (possibly in association with bacteria) releasing organic acids and siderophores. The aetiology of pore formation has been questioned however, with some authors claiming that (all) the observed pores are of abiotic origin (Sverdrup, 2009). Studies of feldspar tunnelling along chronosequences created by postglacial rebound (Hoffland et al., 2002) revealed that the tunnels were more frequent in the uppermost $2 \mathrm{~cm}$ of the $\mathrm{E}$ horizon, that the frequency of tunnelling increased with soil age, and that there was a lag period of up to 2000 years when tunnels were absent or rare, postulated by the authors to coincide with the time taken for the disappearance of the more easily weatherable $\mathrm{K}$ and $\mathrm{Ca}$ containing biotite and hornblende. Parallel studies along productivity gradients (Hoffland et al., 2003) have also revealed a significant positive correlation between the density of ectomycorrhizal root tips and the density of tunnels in the E horizon. However similar tunnels in feldspars across a sand dune chronosequence at Lake Michigan have been estimated to contribute less than $0.5 \%$ of total mineral weathering (Smits et al., 2005), suggesting either that fungal weathering is negligible or that tunnel formation reflects only a small proportion of the total weathering effect of the fungi. The total mineral surface area available for mineral weathering in most mineral soils is clearly much larger than the internal surface area of the observed tunnels, and small tunnel-like features were observed in mineral surfaces by Smits et al. (2005). Different biomechanical mechanisms used by fungi to penetrate rock have received increasing attention. Ultramicroscopic and spectroscopic observations of fungus-biotite interfaces during weathering of biotite flakes have revealed biomechanical forcing and altered interlayer spacing associated with depletion of $\mathrm{K}$ by an ectomycorrhizal fungus (Paxillus involutus; Bonneville et al., 2009). It appears that physical distortion of the lattice structure takes place before chemical alteration through dissolution and oxidation. Fungal hyphae colonising fractures and voids in minerals can exert substantial mechanical force and have been demonstrated to build up turgor pressure in excess of $8 \mathrm{MPa}$ that is sufficient to penetrate Mylar and Kevlar and widen existing cracks in rocks (Howard et al., 1991). Recent studies of biotite colonisation by $P$. involutus (Bonneville et al., 2016) have revealed extensive oxidation of $\mathrm{Fe}$ (II) up to $2 \mu \mathrm{m}$ in depth, and the increase in $\mathrm{Fe}$ (III) implies a volumetric change that is sufficient to strain the crystal lattice and induce the formation of microcracks, which are abundant below the hypha-biotite interface.

The observations of Jongmans et al. (1997) stimulated interest in biogenic weathering and led to a large number of subsequent studies. The endolithic biosignatures of rock-inhabiting microorganisms can be distinguished from purely abiotic microtunnels (McLoughlin et al., 2010). Biological tubular microcavities can be distinguished by their shapes, distribution and the absence of intersections which excludes an origin by chemical dissolution of pre-existing heterogeneities such as radiation damage trails, gas-escape structures or fluid inclusion trails. Atomic force microscopy (AFM) and scanning transmission electron microscopyenergy dispersive X-ray spectroscopy (STEM-EDX) have been used to demonstrate nanoscale alteration of surface topography and attachment and deposition of organic biolayers by fungal hyphae (Bonneville et al., 2011; McMaster, 2012; Gazzè et al., 2013, 2014; Saccone et al., 2012). More recent studies of lizardite dissolution by fungal cells, using confocal laser scanning microscopy (CLSM) (Li et al., 2016), suggest that biomechanical forces of hyphal growth are indispensable for fungal weathering and strong enough to breach the mineral lattice. The data from these studies suggest that biomechanical forcing takes place with micrometrescale acidification mediated by surface-bound hyphae and subsequent removal of chemical elements due to fungal action. However, so far, the quantitative significance of these effects for total weathering rates is still unclear. Comparative studies of forests with either ectomycorrhizal or arbuscular mycorrhizal host tree species (Koele et al., 2014) have revealed the presence of tunnel-like structures in minerals in both types of forest, suggesting that mineral weathering can be caused by acidification of the rhizosphere by both types of mycorrhizal fungus and/or saprotrophic fungi. Investigations of silicate mineral surfaces, buried in proximity to roots of trees that would normally host arbuscular mycorrhizal fungi (AMF) and were growing in an arboretum (Quirk et al., 2012, 2014a), suggest that AMF may also form weathering trenches, although the associated fungi were not identified in these particular studies. Nanoscale channels in chlorite flakes colonised by ectomycorrhizal fungi have also been 
demonstrated (Gazzè et al., 2012) using AFM and suggested as evidence that fungal activity, fuelled by plant photosynthate, can enhance mineral dissolution.

\section{Summary}

Many new studies, published during the past 10 years, using AFM, CLSM, energy dispersive X-ray spectroscopy and vertical scanning interferometry, have revealed the structural alteration of mineral substrates by fungi. The endolithic signatures of rock-inhabiting microorganisms can now be distinguished from structures of abiotic origin but the proportional contribution of tunnels and voids with respect to total biological weathering is probably low since their volume and internal surface area are small in comparison to the total mineral surface area exposed to microbial contact. The capacity of different vegetation systems, hosting different types of mycorrhizal symbionts, to cause structural alteration of different minerals should be investigated in further studies, combined with DNA-based methods to identify the fungi (and bacteria) involved in situ. The influence of environmental factors such as atmospheric $\mathrm{CO}_{2}$ concentration, nitrogen deposition and mineral composition should be investigated.

\section{Biofilms and small-scale microbial interactions with consequences at higher spatial scales}

Most microorganisms do not live as pure cultures of dispersed single cells in soil solution. Instead they aggregate at interfaces - on surfaces of roots, organic matter, rocks and minerals, forming biofilms or microbial mats (Flemming and Wingender, 2010; Flemming et al., 2016). Biofilms consist of a hydrated matrix of extracellular polymeric substances (EPSs), mostly produced by the organisms they contain. This matrix can account for $90 \%$ of the dry mass of the biofilm and provides a structural scaffold responsible for adhesion to surfaces and cohesion of the biofilm, enabling interactions that are entirely different from those of planktonic bacteria. The EPS matrix isolates microorganisms from the bulk soil solution, maintaining them in close proximity to each other and to substrate surfaces, concentrating weathering agents and allowing cell-to-cell communication and quorum sensing by containing and concentrating signal molecules. This permits the formation of synergistic microbial consortia; production, accumulation, retention and stabilisation of extracellular enzymes through binding interactions with polysaccharides; sorption of organic compounds and inorganic ions; redox activity in the matrix (Liu and Lian, 2019); and horizontal gene transfer (Savage et al., 2013; Borgeaud et al., 2015). The retention of water maintains a hydrated microenvironment, protecting against desiccation, and proteins and polysaccharides can provide a protective barrier against specific and non-specific host defences during infection, antimi- crobial agents and some grazing protozoa (Fig. 1a) (Flemming and Wingender, 2010).

Biofilms and microbial mats have been studied from different perspectives that are relevant to interactions between microorganisms and minerals in a biogeochemical context. Subaerial biofilms occur within solid mineral surfaces exposed to the atmosphere and are dominated by fungi, algae, cyanobacteria and heterotrophic bacteria (Gorbushina, 2007). These communities are known to penetrate the mineral substrates and induce chemical and physical changes contributing to weathering. Effects of biofilms containing the phototrophic cyanobacterium Nostoc punctiforme and the rock-inhabiting ascomycete Knufia petricola have been quantified using inductively coupled plasma optical emission spectrometry-mass spectrometry as well as scanning electron microscopy-transmission electron microscopy-energy dispersive X-ray spectrometry (Seiffert et al., 2014), demonstrating clear effects of the biofilms on mineral dissolution and leaching. Mats of hypogeous ectomycorrhizal fungi have been studied by Griffiths et al. (1994), who found that colonisation by Gautieria monticola notably increased the amount of oxalic acid in soil. Calcium oxalate ( $\mathrm{CaOx})$ can accumulate in forest soils, and deposition of $\mathrm{Ca}$ from the weathering of apatite as $\mathrm{CaOx}$ crystals on the hyphal surfaces of Rhizopogon sp. growing from Pinus muricata seedlings has been shown in microcosm studies (Wallander et al., 2002). More $\mathrm{CaOx}$ is formed under higher $\mathrm{P}$ levels (Tuason and Arocena, 2009). Bulk soil solution concentrations of organic acids are considered to be too low to have a large effect on mineral dissolution, and modelling (Smits, 2009) suggests that local concentrations of weathering agents such as oxalate will not have a major effect on feldspar weathering unless the weathering agents remain within a few microns of the mineral surface. However, several authors (Balogh-Brunstad et al., 2008; Finlay et al., 2009) have suggested that higher concentrations of organic acids may accumulate within EPS matrices that are in close proximity to mineral surfaces, so that mineral dissolution is influenced, and have called for more experiments to confirm this possible effect. More recent studies by Gazzè et al. (2013) using atomic force microscopy have demonstrated the presence of EPS halos (Fig. 1b) surrounding Paxillus involutus hyphae colonising phyllosilicate surfaces. In addition to increasing the surface area for hyphal interaction with mineral surfaces, these hydrated EPS layers presumably enhance mineral weathering by promoting accumulation of weathering agents such as organic acids and acidic polysaccharides, but further detailed studies of the local concentrations of these molecules are still necessary.

Fungi and bacteria live together in a wide range of environments (Deveau et al., 2018), and the exudation of carbon compounds from roots and fungal hyphae into biofilms undoubtedly influences bacterial growth and activity (Guennoc et al., 2018). Priming of bacterial activity may occur through supply of exudates from vital hyphae (Toljander et al., 2007) but may also include recycling of $\mathrm{C}$ from damaged or senesc- 


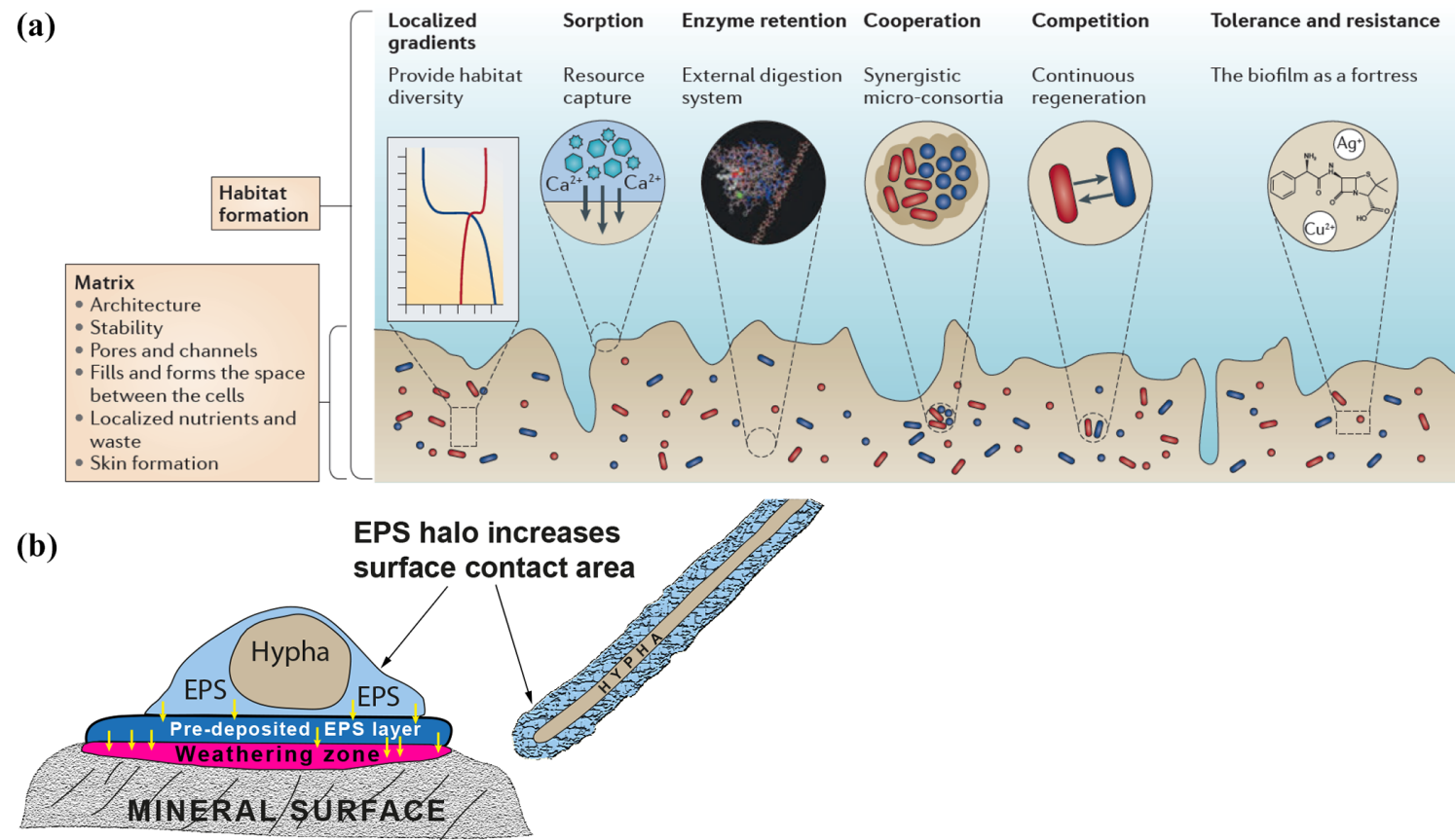

Figure 1. (a) Schematic diagram showing biofilm structure and function and the biological and chemical processes that biofilms influence. (b) Extracellular polymeric substance (EPS) halos and their possible influence on interactions between hypha and mineral surfaces (based on observations by Gazzè et al., 2013). (Figure 1a is reproduced with permission from Flemming et al., 2016.)

ing hyphae. Carbon supply from arbuscular mycorrhizal hyphae can provide energy for associated bacteria to solubilise phosphate (Zhang et al., 2014, 2016). Different ectomycorrhizal fungi colonising lateral roots of tree seedlings have been shown to influence the community structure of associated bacteria (Marupakula et al., 2016, 2017), and differences in the richness and composition of bacterial communities have been demonstrated between the hyphosphere of ectomycorrhizal fungi and that of saprotrophic fungi (Liu et al., 2018). Although the role of bacteria in mineral weathering has been less widely studied than that of fungi in recent years, progress has been made in understanding the identity and mechanisms of bacteria involved in weathering of minerals in acidic forest soils. Bacteria in the genera Burkholderia and Collimonas appear to have significant mineral weathering ability (Uroz et al., 2011), and incubation of different minerals in forest soils appears to result in selection of different bacterial communities, which are distinct from those of the bulk soil (Uroz et al., 2012), confirming the concept of mineralogical control of fungal and bacterial community structure (Gleeson et al., 2005; Hutchens, 2010). Uroz et al. (2015) contrasted the rhizosphere with the "mineralosphere" in which bacteria are selected, not by organic nutrients originating from roots, but by the physiochemical properties of different minerals. Microorganisms can also drive weathering of bedrock in subglacial environments, and the ubiquitous nature of pyrite in many common bedrock types and high $\mathrm{SO}_{4}^{2-}$ concentrations in most glacial meltwater have been interpreted to suggest (Mitchell et al., 2013) that pyrite may be a dominant lithogenic control on subglacial microbial communities and that mineralbased energy may therefore serve a fundamental role in sustaining these microbial populations over glacial-interglacial timescales. Studies by Montross et al. (2013) demonstrated an up to 8-fold increase in dissolved cations in biotic systems containing glacial sediments and meltwater compared with abiotic systems, suggesting that microbial processes can maintain terrestrial chemical weathering rates in cooling climates during glacial advance. Recent experiments attempting to investigate in situ mineral dissolution rates and structure and diversity of bacterial communities colonising silicate minerals (Wild et al., 2018, 2019) have revealed development of mineral-specific bacterial communities and large discrepancies between predicted and measured dissolution rates, which were attributed to "heterogeneity of fluid circulation and local variation in reaction conditions".

\section{Summary}

Consequences of the ecophysiological heterogeneity and spatial organisation of plant-microbe-soil interactions in natural environments need to be incorporated into new models and experimental systems. The effects of biofilms at microbial-mineral interfaces include EPS haloes that increase the surface area of contact, increased concentrations of weathering agents through protection by antibiotic compounds secreted into the EPS matrix, rapid removal of 
feedback-inhibiting weathering products by mycorrhizal hyphae attached to plants that act as strong sinks for mobilised products, and changed patterns of microbial activity due to the facilitation of quorum sensing and other types of signalling. Retention of water within the biofilm matrix may allow weathering to be maintained at higher rates than would otherwise be possible during periods of soil drying. The extremely fine spatial scale of biofilms necessitates further development of sampling at the micrometre-scale to capture the steep chemical gradients and micro-scale variation in chemical and biological diversity and composition. These measurements are essential in order to gain an accurate picture of the chemical and biological conditions existing at weathering interfaces.

\section{Microbial and plant secretions - evidence from microcosms and mesocosms}

Plants play a fundamental role in soil formation since root activity and decomposing plant material enhance weathering rates by producing acidifying substances $\left(\mathrm{H}^{+}\right.$, organic acids) and ligands that complex with metals in the minerals. In addition, uptake of ions released from weathering reduces the likelihood of saturating conditions that retard weathering rates. Many of these effects are mediated by mycorrhizal fungi, and in temperate and boreal forests the vast majority of fine tree roots are colonised by symbiotic ectomycorrhizal fungi.

In ancient, highly weathered soils, $\mathrm{P}$ is the primary nutrient limiting plant growth, whereas $\mathrm{N}$ is the main growthlimiting nutrient in young soils. Plant nutrient acquisition in nutrient-impoverished soils often involves specialised root structures such as cluster roots or symbiotic structures such as mycorrhizal associations or root nodules (Lambers et al., 2008). In ancient soils with very low $P$ availability "dauciform" (carrot-shaped) roots are produced by monocots in the Cyperaceae, and "proteoid" roots are produced by numerous dicot families, including the Proteaceae. Both types of roots are hairy and produce large amounts of carboxylates that desorb P from mineral surfaces. Phosphatases are also produced to release $\mathrm{P}$ from organic sources. Protons are quantitatively important weathering agents, and many biotic processes, including uptake of positively charged nutrients such as $\mathrm{NH}_{4}^{+}$ and $\mathrm{K}^{+}$, result in exudation of protons. Organic acids such as oxalic acid and citric acid are produced by plant roots as well as fungi and bacteria and contribute to proton-driven weathering, but their deprotonated forms also act as strong weathering agents complexing with metals, including $\mathrm{Fe}^{3+}$ and $\mathrm{Al}^{3+}$ (Ma et al., 2001). Soil $\mathrm{P}$ and $\mathrm{N}$ change as a function of soil age, and in younger- and intermediate-aged soils with adequate amounts of nutrients, mycorrhizal mycelia provide an effective strategy for nutrient acquisition (Lambers et al., 2008). Experiments using dual isotopic tracers of ${ }^{14} \mathrm{C}$ and ${ }^{33} \mathrm{P}$ suggest that evolution of land plants from rootless game- tophytes to rooted sporophytes with larger arbuscular mycorrhizal hyphal networks enabled enhanced efficiency of $\mathrm{P}$ capture as atmospheric $\mathrm{CO}_{2}$ concentrations fell during the mid-Palaeozoic (480-360 Myr ago; Field et al., 2012).

Strategies of mycorrhizal symbiosis differ depending upon the plant host. The majority of plant species form arbuscular mycorrhizal associations with Glomeromycotan fungi that are efficient at scavenging nutrients such as $\mathrm{P}$ and transporting it to their plant hosts across the depletion zones around roots formed by the slow diffusion of $\mathrm{P}$ through soil. However, these fungi are less efficient than proteoid roots at "mining" $\mathrm{P}$ and releasing it from sorbed forms. Ericoid mycorrhizal associations are formed by plants in the Ericaceae, Empetraceae and Epacridaceae, and ectomycorrhizal associations are formed by many woody plants and trees (Smith and Read, 2008). The fungi forming these two types of symbiosis vary in their enzymatic competence, but in general they have a more highly developed capacity to both scavenge and mine $\mathrm{N}$ and $\mathrm{P}$ than arbuscular mycorrhiza, releasing $\mathrm{N}$ and $\mathrm{P}$ from organic forms (in the case of ectomycorrhizal fungi) by different combinations of hydrolytic and oxidative enzymes and non-enzymatic Fenton chemistry (Lindahl and Tunlid, 2015; Nicolás et al., 2019) and P and other mineral elements from inorganic forms via proton, organic acid, and siderophore exudation. In boreal forests with stratified podzol soils, many ectomycorrhizal fungal species produce extensive fungal mycelia that colonise both organic soil horizons and mineral horizons to an equal extent on a land area basis (Söderström, 1979), although data expressed on a soil dry weight basis often suggest that colonisation of the mineral soil is lower since the mineral soil has a dry weight approximately 10 times higher than the organic soil. Studies of vertical distribution of different functional guilds of fungi (Lindahl et al., 2007; Sterkenburg et al., 2018) suggest that ectomycorrhizal fungi are more abundant than saprotrophs in deeper organic and mineral horizons, presumably because they receive supplies of carbon from their plant hosts and are less reliant on local sources of carbon that are less abundant in the deeper horizons.

Mycorrhizal fungal mycelia secrete a wide range of molecules and the secretome has been shown to include lowmolecular-weight (LMW) organic acids, amino acids, polyols, peptides, siderophores, glycoproteins and a diverse range of enzymes such as proteases, phosphatases, lignin peroxidases and laccase. The production of these substances is highly variable both within and between different types of mycorrhizal fungi and influenced by different environmental conditions. Figure 2 illustrates the flow of plant-derived carbon compounds through the fungal mycelium, the secretion of compounds into extracellular polysaccharide matrices and the soil solution and the longer-term immobilisation processes that result in storage of stable $\mathrm{C}$ in organic and mineral pools. Although many of the molecules produced by the mycelium and its associated bacteria are labile and subject to rapid turnover, they play a collective role in mobilisation of 


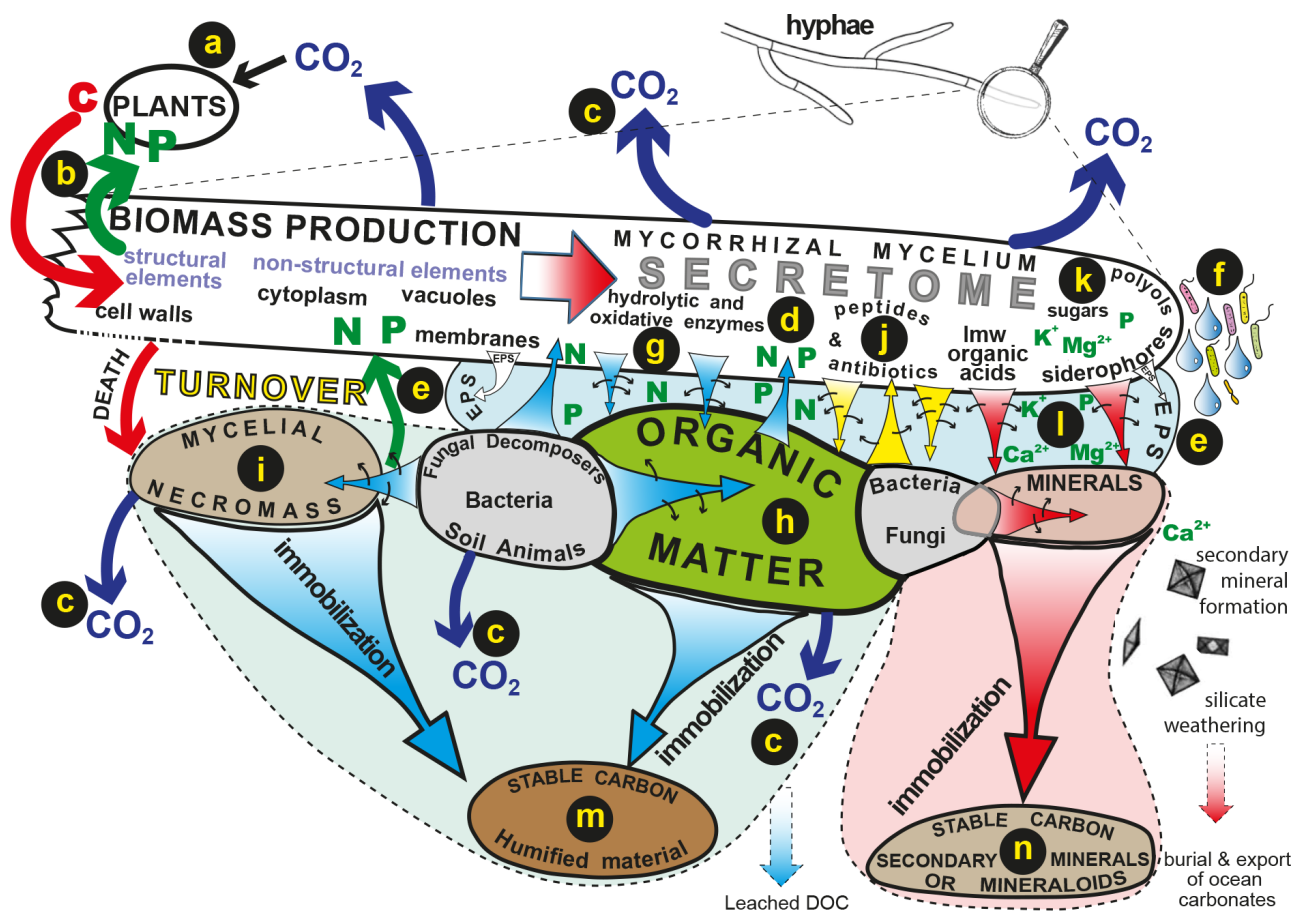

Figure 2. The flow of plant-derived carbon through fungal hyphae to organic and inorganic substrates drives biogeochemical processes such as decomposition and weathering and influences patterns of $\mathrm{C}$ release and sequestration into stable organic and inorganic forms. Carbon is assimilated by plants (a) and transferred directly to symbiotic mycorrhizal hyphae that transfer nutrients mobilised by the hyphae back to their hosts (b). Products of mycelial respiration are released to the atmosphere (c). The fungal secretome (d) consists of different labile compounds that can be translocated to different organic or inorganic substrates. These compounds may be released into an extracellular polysaccharide matrix (e) or as droplets that condition the hyphosphere, facilitating interactions with bacteria (f). Hydrolytic and oxidative enzymes (g) mobilise N and P from plant-derived organic substrates (h) or microbial necromass (i). Peptides and antibiotics play important roles in signalling and influencing microbiome structure $(\mathrm{j})$, sugars and polyols maintain osmotic gradients and hyphal turgor (k), and lowmolecular-weight organic acids and siderophores influence the mobilisation of $\mathrm{P}$ and base cations from minerals (1). Long-term sequestration and stabilisation of carbon can take place in recalcitrant organic substrates (m) and secondary minerals and mineraloids (n) (reproduced with permission; Finlay and Clemmensen, 2017).

nutrients that can lead to a longer-term sequestration of $\mathrm{C}$ in recalcitrant substrates that are both organic (Clemmensen et al., 2013) and inorganic (Sun et al., 2019a).

LMW organic acids are frequently identified as important components of the exudates produced by ectomycorrhizal fungi. Simple carboxylic acids are often present in soil solution and implicated in pedogenic processes. Their sorption characteristics were studied by van Hees et al. (2003), who found adsorbed-to-solution ratios as high as 3100 . Organic acids are readily adsorbed to the solid phase and sorption provides an important buffering role in maintaining soil solution concentrations at low organic acid concentrations, inhibiting microbial degradation. Concentrations of LMW organic compounds in soil solution are typically low $(<50 \mu \mathrm{M})$, but the flux through this pool is extremely rapid and microbial mineralisation to $\mathrm{CO}_{2}$ results in mean residence times of 1-10 h (van Hees et al., 2005). These labile compounds may thus make a substantial contribution to the total efflux of $\mathrm{CO}_{2}$ from soil. Direct measurements of oxalate exudation from hyphal tips of the ectomycorrhizal fungus Hebe- loma crustuliniforme (van Hees et al., 2006) have led to calculated exudation rates of $19 \pm 3 \mathrm{fmol}$ oxalate per hyphal tip per hour, suggesting that concentrations of $30 \mathrm{mM}$ oxalate could occur within $1 \mathrm{~h}$ inside feldspar tunnels occupied by fungal hyphae. This would represent a concentration 10000 times higher than in the surrounding soil solution. Production of the hydroxamate siderophore ferricrocin was also detected and calculated to be able to reach a concentration of $1.5 \mu \mathrm{M}$, around 1000 times higher than in the surrounding soil solution. Interestingly, the steady-state dissolution of goethite by 2'-deoxymugineic acid (DMA) phytosiderophores has been demonstrated to be synergistically enhanced by oxalate (Reichard et al., 2005), and it is possible that synergistic interactions between other combinations of organic acids and siderophores may exist. Organic acid production by intact ectomycorrhizal fungal mycelia colonising Pinus sylvestris seedlings was studied by Ahonen-Jonnarth et al. (2000), using axenic in vitro systems. In this study, production of oxalic acid by seedlings exposed to elevated $(0.7 \mathrm{mM}) \mathrm{Al}$ and colonised by Suillus variegatus or Rhizo- 
pogon roseolus was up to 39.5 and 26 times, respectively, higher than in non-mycorrhizal control plants. The same type of lab system was used by Johansson et al. (2009) to investigate the effect of different mycorrhizal fungi on production of LMW organic acids, amino acids and dissolved organic carbon (DOC). However, in these experiments the identifiable LMW organic acids constituted only a small proportion $(3 \%-5 \%)$ of the total DOC fraction, but DOC production was increased in mycorrhizal treatments relative to the nonmycorrhizal controls.

Studies of mycorrhizal hyphal exudates using nuclear magnetic resonance (NMR) spectroscopy (Sun et al., 1999) have revealed exudation of fluid droplets at the hyphal tips of the ectomycorrhizal fungus Suillus bovinus and found that sugars and polyols comprised $32 \%$ and peptides $14 \%$ of the exudate mass. Oxalic acids and acetic acid were also found, and polyols such as mannitol and arabitol are thought to be important for retaining turgor in fungal hyphae during $\mathrm{C}$ translocation along hydrostatic pressure gradients. High internal pressures in hyphae are thought to be an evolutionary adaptation to facilitate penetration of both plant tissues and rock surfaces (Jongmans et al., 1997). This exudation of droplets may play an important role in conditioning the immediate environment of hyphal tips, facilitating interactions with substrates and associated microorganisms, even in drier soils. Similar observations have been made by Querejeta et al. (2003), who demonstrated that water obtained by Quercus agrifolia plants, using hydraulic lift, can be transferred to associated arbuscular mycorrhizal and ectomycorrhizal fungi to maintain their integrity and activity during drought, even when the fertile upper soil is dry. Carbon allocation in the form of sugars and polyols (Sun et al., 1999) may be important in generating turgor pressure in hyphae and has consequences for weathering of minerals with lattice structure.

While biologically derived molecules such as organic acids and siderophores are strongly implicated in promoting mineral weathering, it is important to note that biologically derived ligands may also inhibit mineral weathering. Among LMW organic acids, only citric and oxalic acids are commonly observed to stimulate mineral weathering (Neaman et al., 2006; Drever and Stillings, 1997), and humic and fulvic acids, which may dominate dissolved organic matter in soil solutions, have been observed to exert an inhibitory effect on mineral dissolution (Ochs, 1996; Drever and Stillings, 1997).

Different microcosm systems have been used to study interactions between minerals and mycorrhizal fungal mycelia colonising plant seedlings. Differential allocation of plantderived $\mathrm{C}$ to patches of primary minerals such as quartz and potassium feldspar (Rosling et al., 2004) and to apatite and quartz (Smits et al., 2012) suggests tightly coupled plantfungal interactions underlying weathering. In the experiment by Smits et al. (2012), when P was limiting, 17 times more ${ }^{14} \mathrm{C}$ was allocated to wells containing apatite than to those containing only quartz, and fungal colonisation of the substrate increased the release of $\mathrm{P}$ by a factor of almost 3 .
Experiments by van Schöll et al. (2006a) demonstrated that limitation of nutrients $(\mathrm{P}, \mathrm{Mg}, \mathrm{K})$ affected the composition of organic acids exuded by ectomycorrhizal fungi (more oxalate) but not the total amounts. Other experiments by van Schöll et al. (2006b) have demonstrated significant weathering of muscovite by the ectomycorrhizal fungus Paxillus involutus when $\mathrm{K}$ was in low supply whereas no effect on hornblende was found under $\mathrm{Mg}$ deficiency. Selective allocation of biomass to grains of different minerals by $P$. involutus has also been demonstrated (Leake et al., 2008; Smits et al., 2008), suggesting grain-scale "biosensing"; however it is also possible that fungal growth may be influenced by topographic structure (Smits and Wallander, 2017). Schmalenberger et al. (2015) demonstrated mineral-specific exudation of oxalate by $P$. involutus using labelled ${ }^{14} \mathrm{CO}_{2}$ given to the host plant. Oxalate was exuded in response to minerals in the following sequence: Gabbro > limestone, olivine and basalt $>$ granite and quartz. Experiments using flow-through systems (Calvaruso et al., 2013) have also estimated weathering rates of apatite to be 10 times higher when pine seedlings were present, compared with unplanted systems, and attributed this to exudation of organic acids by the roots. The plants had been checked for the absence of fungal "contaminants" but inoculation with the mineral weathering bacterial strain Burkholderia glathei PML1(12)Rp appeared to have no significant effect on weathering.

Fungi, bacteria and plants all produce siderophores, lowmolecular-mass, metal-complexing compounds. These bind strongly to $\mathrm{Fe}^{3+}$, influencing its release and uptake (Kraemer et al., 2014; Ahmed and Holmström, 2014). The hydroxamate siderophores ferrichrome and ferricrocin have been found in a soil solution of more layer podzolic soil overlying granitic rock and intensively colonised by ectomycorrhizal hyphae (Holmström et al., 2004) and should be kinetically and thermodynamically even more efficient complexing agents for trivalent cations than oxalic and citric acid. Primary minerals containing substantial amounts of $\mathrm{Fe}$, such as hornblende and biotite, show enhanced dissolution rates in the presence of bacterial or fungal siderophores (Kalinowski et al., 2000; Sokolova et al., 2010), and attachment of microorganisms to the mineral surfaces appears to lead to greater dissolution of elements from biotite (Bonneville et al., 2009; Ahmed and Holmström, 2015).

Release of potassium from K-feldspar and illite in microcosms by the fungus Aspergillus fumigatus was demonstrated by Lian et al. (2008), who showed that release of $\mathrm{K}$ was enhanced by a factor of 3-4 by physical contact between the fungus and the mineral surface. Simple types of microcosm are usually used for gene expression studies in order to facilitate extraction of RNA from target organisms. Xiao et al. (2012) used differential expression cDNA libraries of A. fumigatus using suppression subtractive hybridisation technology to investigate the mechanisms by which the fungus weathered K-bearing minerals. K-bearing minerals were found to upregulate the expression of carbonic anhy- 
drase (CA), implying that A. fumigatus was capable of converting $\mathrm{CO}_{2}$ into carbonate to accelerate the weathering of potassium-bearing minerals, which fixed $\mathrm{CO}_{2}$. During mineral weathering, the fungus changed its metabolism, produced more metal-binding proteins and reduced membrane metal transporter expression, which can modulate ion absorption and disposal and promote acid production. Wang et al. (2015) used high-throughput RNA sequencing (RNAseq) to study the molecular mechanisms of Aspergillus niger involved in weathering of potassium feldspar. The fungus was cultured with soluble $\mathrm{K}^{+}$or $\mathrm{K}$-feldspar, demonstrating differential expression of genes related to synthesis and transportation of organic acids, polysaccharides and proteins, which was closely related to release of $\mathrm{K}^{+}$from the minerals. Regulation of carbonic anhydrase (CA) gene expression in Bacillus mucilaginosus and the effects of its expression product in Escherichia coli have been examined by Xiao et al. (2014), who found that expression of CA genes was upregulated by the addition of calcite to a $\mathrm{Ca}^{2+}$-deficient medium and that a crude enzyme extract of the expression product in E. coli promoted calcite dissolution. Real-time fluorescent, quantitative polymerase chain reaction (PCR) has been used to explore the correlation between CA gene expression in B. mucilaginosus and deficiency or sufficiency of $\mathrm{Ca}$ and $\mathrm{CO}_{2}$ concentration, and the results suggest that $\mathrm{CA}$ gene expression is negatively correlated with both $\mathrm{CO}_{2}$ concentration and the ease of obtaining soluble calcium (Xiao et al., 2015). The roles of different CA genes have also been studied in Aspergillus nidulans using gene deletion, overexpression and bioinformatics (Sun and Lian, 2019), and the results of this study suggest that the CA gene canA is involved in weathering of silicate minerals and carbonate formation, catalysing $\mathrm{CO}_{2}$ hydration, and that $\operatorname{canB}$ is essential for cellular respiration and biosynthesis in low- $\mathrm{CO}_{2}$ environments. Recent microcosm studies have also used transcriptome analysis to investigate weathering of K-containing feldspar and apatite and demonstrated upregulation of high-affinity ion transporter systems in the ectomycorrhizal fungus Amanita pantherina (Sun et al., 2019b).

\section{Summary}

Earlier microcosm demonstrations of selective allocation of carbon to different minerals by ectomycorrhizal mycelium have now been complemented by newer studies demonstrating that selective $\mathrm{C}$ allocation to nutrient-containing minerals through intact ectomycorrhizal mycelium results in significant increases in nutrient uptake by the host plants (Smits et al., 2012). There is still disagreement about the relative importance of different molecules as weathering agents, and better information is required about their chemical identity, concentration and rates of turnover at weathering interfaces. Advances in DNA-based techniques have enabled a range of microcosm experiments in which the regulation of weathering interactions between fungi and minerals has been exam- ined in microcosms, and further studies based on transcriptomics will provide a more detailed understanding of how weathering of different minerals is regulated in individual species. However, DNA-based community profiling methods should also be used to improve understanding of more complex weathering consortia involving both bacteria and fungi.

\section{Systemic consequences of microorganism-mineral interactions in an ecological and evolutionary context}

There is strong support for the idea that microorganismmineral interactions have important consequences at global spatial scales and evolutionary timescales and some of these are illustrated in Fig. 3. Indeed, the concept of "mineral evolution" (Hazen et al., 2008) suggests that over two-thirds of the number of minerals that exist today (>5300) are the result of chemical changes mediated by living organisms (Fig. 3a). The best known of these is the Great Oxidation Event about 2.3 billion years ago ( $2.3 \mathrm{Ga}$ ) (Kump, 2008; Luo et al., 2016) during which the Earth's atmosphere changed from one that was almost devoid of oxygen to one that is one-fifth oxygen. Inclusions of potentially biogenic carbon within Hadean zircons as old as $4.1 \mathrm{Ga}$ (Bell et al., 2015) suggest that biological processes could have been operating during the Hadean Eon. Early microbial communities would have developed within subsurface mineral environments to avoid high levels of ionising radiation at the interface between the atmosphere and lithosphere. The subaerial biofilms at this interface today remain stressful environments (Gorbushina, 2007), but ionising radiation levels are now much lower due to thickening of the Earth's atmosphere. Biomarker evidence (Brocks et al., 1999) in rocks formed 200 million years (Myr), before the increase in atmospheric oxygen, suggests that oxygen was already being produced before $2.5 \mathrm{Ga}$. Oxygenic photosynthesis by cyanobacteria is a likely source of this oxygen but there is evidence that stromatolites were abundant between 3.4 and $2.4 \mathrm{Ga}$, prior to the advent of cyanobacteria and oxygenic photosynthesis (Allen, 2016), and that Archaean microbial mats of protocyanobacteria switched between photolithoautotrophic and photoorganoheterotrophic metabolism prior to the evolution of cyanobacteria with simultaneous, constitutive expression of genes allowing both types of metabolism. It is also likely that phototrophy based on purple retinal pigments similar to the chromoprotein bacteriorhodopsin, discovered in halophilic Archaea, may have dominated prior to the development of photosynthesis (DasSarma and Schweiterman, 2018). The activity of these early microorganisms and subsequent accumulation of oxygen in the atmosphere paved the way for the evolution of plants, and there is a large and diverse body of evidence that the plastids of algae and higher plants evolved from free-living bacteria by endosymbiosis involving endosymbiotic gene transfer (Zimorski et 


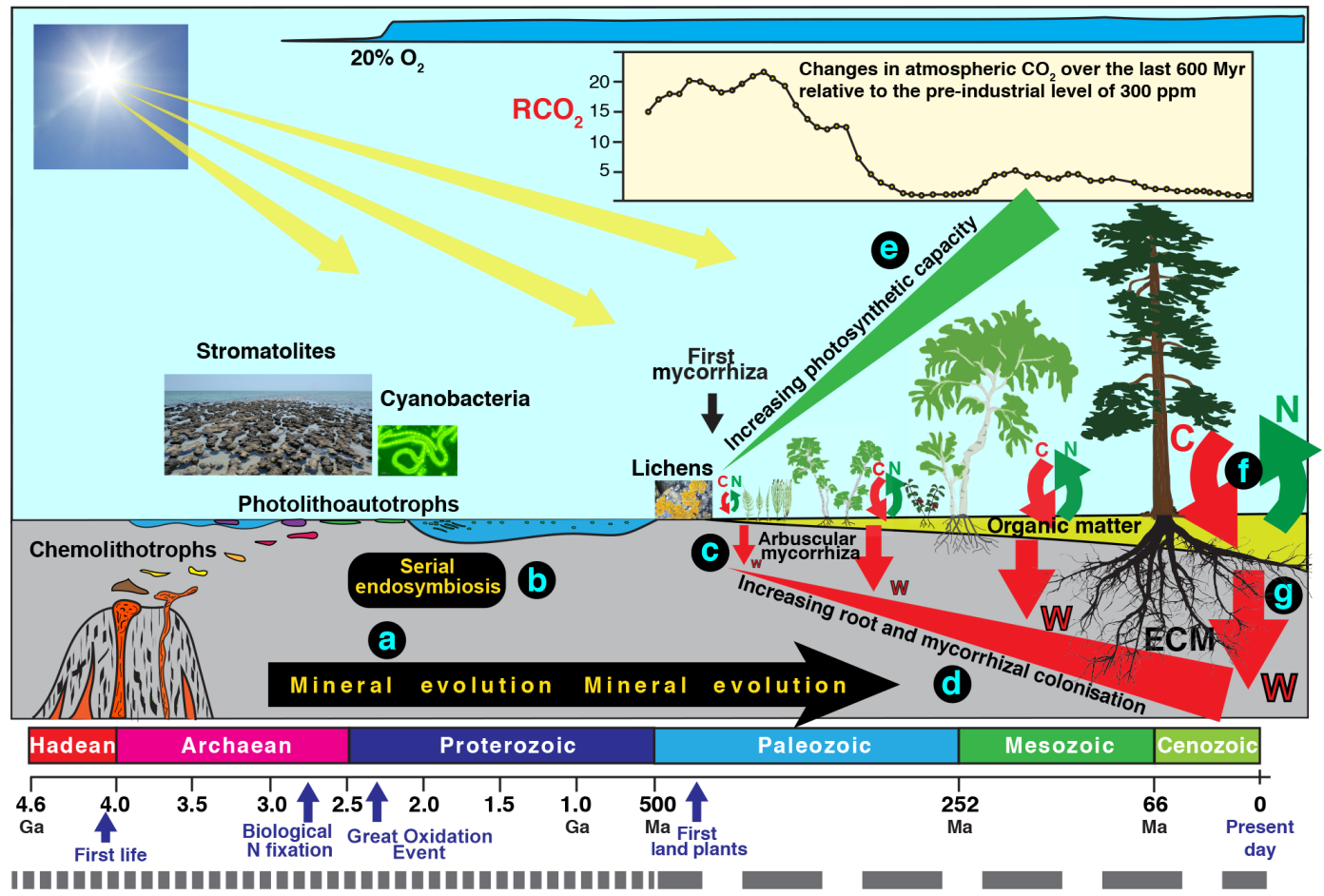

Figure 3. Schematic diagram summarising an evolutionary perspective of interactions involving mineral weathering and decomposition. Current rates of mineral weathering have been influenced by different "events" and processes, including the effects of biological processes on mineral evolution (a), serial endosymbiosis (b) enabling the evolution of higher plants, and mycorrhizal symbiosis (c) enabling increasing colonisation of substrates by roots and mycorrhizal mycelium (d), leading to more efficient nutrient uptake and larger amounts of photosynthetic tissue (e). The evolution of ectomycorrhizal fungi (ECM) has enabled efficient extraction of $\mathrm{N}$ and $\mathrm{P}$ from recalcitrant organic material (f) powered by higher $\mathrm{C}$ allocation and better colonisation of organic and mineral substrates (f, $g$ ). Note the timescale of the most recent 500 million years is expanded by a factor of approximately 8 .

al., 2014) as well as horizontal gene transfer (Archibald, 2015) (Fig. 3b).

Evolution of higher plants and development of vegetation has had a substantial effect on mineral weathering. The first well-differentiated forests appeared in the Devonian, and increases in the volume of roots from the Silurian to the Devonian are associated with increases in clay enrichment and chemical weathering in subsurface horizons and drawdown of atmospheric $\mathrm{CO}_{2}$ (Retallack, 1997). Dissolution of bedrock, accelerated by growth of plants and enhanced weathering of silicates, resulting in $\mathrm{HCO}_{3}^{-}$carried to the sea and precipitated as carbonates, would have led to removal of $\mathrm{CO}_{2}$ from the atmosphere. Further, the large drop in $\mathrm{CO}_{2}$ during the Devonian 400-360 Myr ago is thought to be associated with the rise of land plants and spread and development of forests (Berner, 1997).

The ubiquitous distribution of microorganisms today suggests that plants are not stand-alone entities but should be considered from a holistic perspective, as holobionts, including the full diversity of the many different microorganisms associated with them (Vandenkoornhuyse et al., 2015). Almost all plant roots are colonised by microbial symbionts, making it difficult to quantify the separate contributions of plants and associated microorganisms to mineral weathering. There is broad agreement that fungi are important biotic agents of geochemical change (see Gadd, 2010, 2013a, $b, 2017$ ) and that coevolution of fungi and plants has enabled them to have increasing influence as biogeochemical engineers (Fig. 3c-g). Fungi exert significant influence on biogeochemical processes, especially in soil, rock and mineral surfaces and the plant root-soil interface where mycorrhizal fungi are responsible for major mineral transformations, redistribution of inorganic nutrients and flow of $\mathrm{C}$. They are important components in rock-inhabiting communities with roles in mineral dissolution and secondary mineral formation. The ubiquity and significance of lichens as pioneer organisms in the early stages of mineral soil formation, and as a model for understanding weathering in a wider context, have been discussed by Banfield et al. (1999) and Chizhikova et al. (2016). In lichens, photosynthetically fixed C is transferred from the photobionts (green algae and cyanobacteria) to a fungal thallus in contact with the mineral surfaces. Non-photosynthetic prokaryote assemblages are also present in a zone of microbially mediated weathering where mineral surfaces are covered in complex mixtures of highmolecular-weight polymers, clays and oxyhydroxides, and 
mineral weathering is accelerated via polymer-mediated dissolution, transport or recrystallisation. Increasing evidence suggests that these bacteria are integral components of lichen thalli, contributing to the overall fitness of the lichen in functionally diverse ways (Grube et al., 2015) and that the structure of the bacterial microbiome is influenced by the identity of the photoautotrophic symbionts (Hodkinson et al., 2012). Whilst the functional roles of these bacteria are still poorly understood, some have been demonstrated to solubilise phosphate (Sigurbjörnsdóttir et al., 2015). There are similarities in the carbon compounds produced by fungi forming lichens and other fungi, but in later successional stages other types of symbiosis occur, involving mycorrhizal plants. Furthermore, throughout evolution successive increases in the size of plants (Quirk et al., 2015) have allowed larger amounts of carbon to be allocated to larger root systems and greater amounts of mycorrhizal mycelium and exudates - increasing their potential for interacting with mineral substrates. Although the genetic potential for hydrolytic decomposition of cellulose and other plant cell wall components has contracted in comparison with their saprotrophic ancestors (Kohler et al., 2015; Martin et al., 2016), saprotrophic fungi also exude the same types of carbon compounds as ectomycorrhizal fungi, including organic acids. Paxillus involutus, an ectomycorrhizal species derived from a clade of brown-rot fungi, appears to have retained the non-enzymatic Fenton chemistry used by brown-rot fungi to extract $\mathrm{N}$ from organic matter (Nicolás et al., 2019). P. involutus produces oxalate and weathers minerals, and it is possible that different organic acids have multiple effects beyond weathering. However, as far as we are aware, differences in organic acid production have not yet been studied comprehensively from an evolutionary perspective. Fahad et al. (2016) compared mobilisation of base cations and $\mathrm{P}$ from granite particles by saprotrophic and ectomycorrhizal fungi in vitro and found statistically higher levels of accumulation of $\mathrm{Mg}, \mathrm{K}$ and $\mathrm{P}$ by the ectomycorrhizal fungi, but only a few species were examined and further systematic comparisons of larger numbers of species need to be conducted to establish the generality of this result. Symbiotic ectomycorrhizal fungi are thought to have evolved repeatedly and independently from saprotrophic precursors, so there should have been selection for ectomycorrhizal fungi that can efficiently mobilise nutrients and transfer them to the large sinks created by their host trees. However there have also been multiple reversals from the symbiotic habit to the free-living saprotrophic habit (Hibbett et al., 2000), so caution should be exercised in generalisations based on lab experiments. In vitro experiments, in which fungi are cultured without their host plants, also introduce artefacts since the host plants act as important sinks for weathering products, preventing feedback inhibition of weathering processes due to accumulation of reaction products.

Many studies of ectomycorrhizal influence on weathering rates have been performed over short periods and do not al- ways provide clear evidence that processes observed at the laboratory scale play a significant role in "soil-scale" mineral dissolution rates. Smits et al. (2014) used a vegetation gradient from bare soil, via sparse grass to Norway spruce forest in a natural lead-contaminated area in Norway to study longterm effects of vegetation on apatite weathering in moraine deposited at the end of the last glaciation. Vegetation had a strong stimulatory effect on apatite weathering, and $75 \%$ of the variation in apatite weathering could be explained by soil $\mathrm{pH}$, but the effect of plant roots and mycorrhizal symbionts on this process could not be separated. In the top $20 \mathrm{~cm}$ of the mineral soil, an additional mechanism, not mediated by $\mathrm{pH}$, enhanced dissolution of apatite. The authors suggested this might be caused by organic acids, leading to higher concentrations of the organic-metal complexes on the mineral surfaces but that the origin of these acids was probably not ectomycorrhizal fungi since these fungi were absent in the grass vegetation at the highest $\mathrm{pH}$ area of the vegetation gradient. Under these conditions, the biomechanical and chemical effects of ectomycorrhizal fungi on apatite weathering seemed to be minor, but these effects are probably dependent on the nutrient status of the forest. Enhanced colonisation of apatite by ectomycorrhizal hyphae in laboratory systems (Rosling et al., 2004; Smits et al., 2012) is also commonly found under field conditions, but only when $\mathrm{P}$ availability is low (Rosenstock et al., 2016; Bahr et al., 2015; Almeida et al., 2019). The potential for weathering by ectomycorrhizal fungi is probably much higher under these conditions and the nutrient status of the forest should be considered when biological weathering rates are quantified, at least for apatite weathering, where $\mathrm{P}$ status has a strong effect on fungal colonisation of apatite. In contrast, no enhanced colonisation of biotite and hornblende by ectomycorrhizal hyphae was found in Norway spruce forests in the Czech Republic under low $\mathrm{K}$ or $\mathrm{Mg}$ availability (Rosenstock et al., 2016). This suggests that ectomycorrhizal fungi have a smaller potential to enhance weathering of these minerals compared to apatite. However, these results should be treated with caution since no quantitative or chemical estimates of the mineral weathering were made, and use of ergosterol-based estimates of fungal biomass as a proxy for weathering can be misrepresentative, since some ectomycorrhizal fungi that actively release LMW organic acids may not invest much carbon in their own biomass. Further investigations using RNAbased analysis of active microbial communities, combined with temporal assessment of weathering kinetics, should reveal the true potential of microorganisms in biogeochemical weathering in forest ecosystems. Effects of $\mathrm{N}$-fixing microorganisms on weathering activity have not been studied in detail but the resulting inputs of $\mathrm{N}$ might be expected to drive growth and increase demand for rock-derived nutrients. Recent studies by Perakis and Pett-Ridge (2019) based on uptake of strontium ( $\mathrm{Sr}$ ) isotopes suggest that nitrogen-fixing red alder (Alnus rubra) trees can take up significantly more rock-derived $\mathrm{Sr}$ than five other co-occurring tree species, al- 


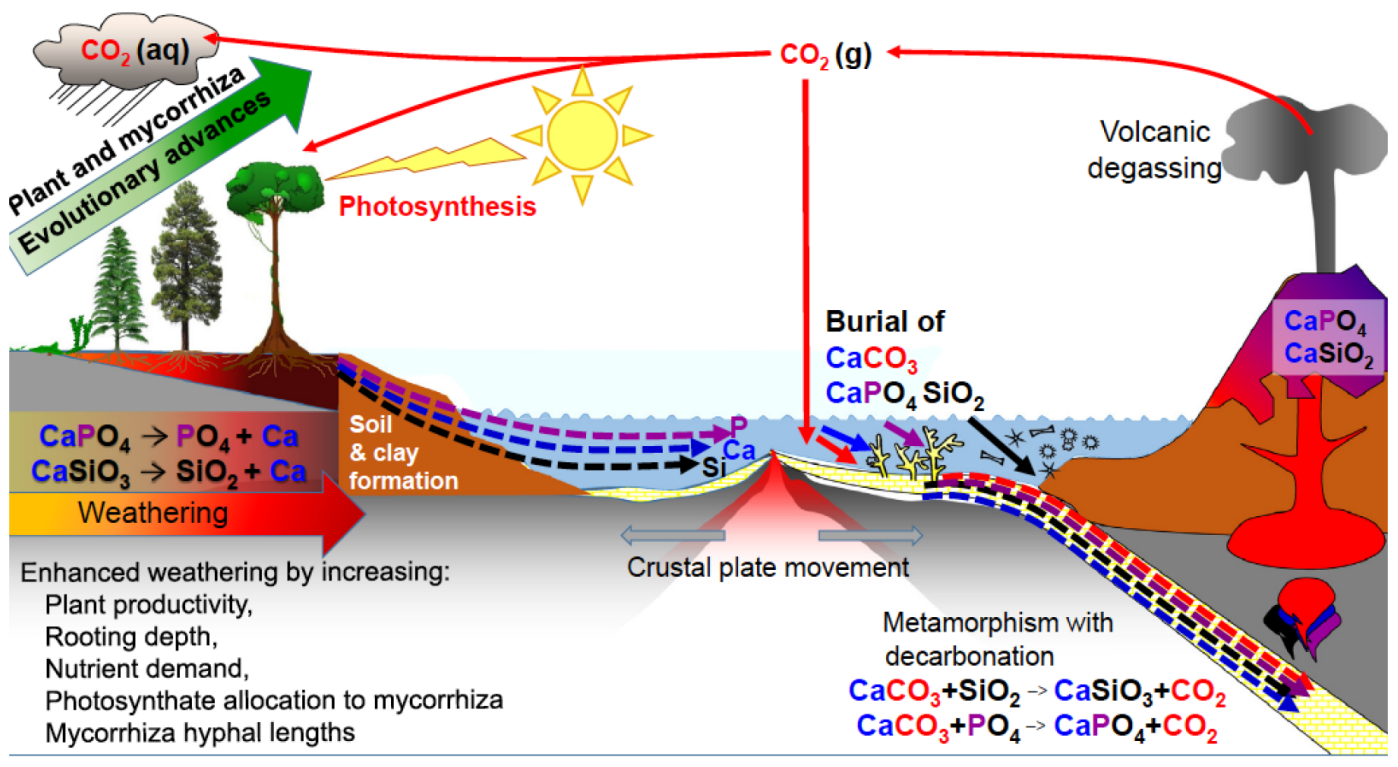

Figure 4. The effects of evolutionary advancement in plants and mycorrhizal associations in the geochemical carbon cycle, increasing the weathering of calcium $(\mathrm{Ca})$-, phosphorus $(\mathrm{P})$-, and silicon $(\mathrm{Si})$-bearing minerals and generating clays. Plants and their mycorrhizal fungi have increased the rates of dissolution of continental silicates, especially calcium silicate $\left(\mathrm{CaSiO}_{3}\right)$, and apatite $(\mathrm{Ca}$ phosphate-CaPO 4$)$, but a portion of the $\mathrm{Ca}, \mathrm{P}$ and $\mathrm{Si}$ released from rocks is washed into the oceans where these elements increase productivity. Some of the Ca and $\mathrm{P}$ ends up in limestone and chalk deposits produced by marine organisms such as corals and foraminifera, thereby sequestering carbon dioxide $\left(\mathrm{CO}_{2}\right)$ that was dissolved in the oceans into calcium carbonate $\left(\mathrm{CaCO}_{3}\right)$ rock for millions of years. Dissolved Si is used in sponges, radiolarians and diatoms that can accumulate on the sea floor. The ocean sediments are recycled by subduction or uplift by tectonic forces, with volcanic degassing and eruptions of base-rich igneous rocks such as basalt returning $\mathrm{Ca}, \mathrm{P}, \mathrm{Si}$ and other elements back to the continents, thereby reinvigorating ecosystems with new nutrient supplies through weathering. Note for simplicity that magnesium is not shown in the figure but follows parallel pathways to $\mathrm{Ca}$ and is co-involved in sequestering $\mathrm{CO}_{2}$ into dolomitic limestones. aq, liquid state; g, gaseous state. (Figure is reproduced with permission: Leake and Read, 2017.)

though the mycorrhizal fungi colonising these trees were not identified.

Fungal weathering of rocks and minerals through biomechanical and biochemical attack has been studied extensively. Proton-promoted dissolution is supplemented by ligandpromoted dissolution of minerals by strong chelators such as oxalic and citric acid that may act synergistically with siderophores. Secondary minerals may be deposited as carbonates, oxalates, or other mycogenic minerals and mineraloids, and the role of "rock-building fungi" has been discussed in addition to the role of "rock-eating fungi" (Fomina et al., 2010). Fungi are prolific producers of oxalate, and oxalotrophic bacteria are capable of oxidising calcium oxalate to calcium carbonate. Since the oxalate is organic in origin, and half its $\mathrm{C}$ is transformed into mineral $\mathrm{C}$ with a much longer residence time, this process represents a potential major sink for sequestration of atmospheric C (Verrecchia et al., 2006). Precipitation of carbonate minerals by microorganisms during silicate weathering has also been discussed by Ferris et al. (1994) in relation to its potential role as a sink for atmospheric $\mathrm{CO}_{2}$. The oxalate-carbonate pathway may not be important in boreal forest soils; however the African oxalogenic iroko tree Milicia excelsa, together with associated saprotrophic fungi and bacteria, enhances carbonate pre- cipitation in tropical Oxisols, where such accumulations are not expected due to the acidic nature of the soil (Cailleau et al., 2011), and the same phenomenon has been demonstrated in acidic soils of a Bolivian tropical forest (Cailleau et al., 2014). Studies of bacterial assemblages in soil associated with ectomycorrhizal roots of Pinus massoniana and Quercus serrata have revealed enrichment of oxalotrophic bacteria using the oxalate-carbonate pathway, representing a potential long-term sink for photosynthetically fixed carbon derived from the atmosphere (Sun et al., 2019a). The role of microorganisms in dissolution and modification of karst stones such as limestone and dolomite has also been studied (Lian et al., 2010, 2011). Microbially mediated chemical corrosion and precipitation in surface and underground water can play a role in pedogenesis and provide a sink for atmospheric $\mathrm{CO}_{2}$, and the role of carbonic anhydrase in hydrating atmospheric $\mathrm{CO}_{2}$ to $\mathrm{HCO}_{3}^{-}$has been investigated in relation to changes in $\mathrm{CO}_{2}$ concentration and availability of $\mathrm{Ca}^{2+}$ (Xiao et al., 2014, 2015). The results of the latter study suggest that the importance of microbial carbonic anhydrase on silicate weathering and carbonate formation may be higher at current $\mathrm{CO}_{2}$ levels than under primordial conditions $2 \mathrm{Myr}$ ago when $\mathrm{CO}_{2}$ levels were much higher. 
Rapid decreases in soil respiration following the girdling of forest trees (Högberg et al., 2001) suggest that the flux of current assimilates to mycorrhizal roots is directly connected to the supply and respiration of $\mathrm{C}$ in soil. In another study (Högberg and Högberg, 2002), extractable DOC in a 50-yearold boreal forest was $45 \%$ lower in girdled plots than in control plots, suggesting a large contribution by roots and associated fungi to soluble-C pools, although the contribution of these two components could not be determined separately. Biogeochemical weathering of silicate rocks is a key process in the carbon cycle (Pagini et al., 2009), and, although consumption of $\mathrm{CO}_{2}$ by weathering is small compared with transfers associated with photosynthesis and respiration, it is the dominant sink in global carbon balance and controls atmospheric $\mathrm{CO}_{2}$ and climate patterns at scales of millennia or longer (Goudie and Viles, 2012).

The geoengineering potential of artificially enhanced silicate weathering is now increasingly well established (Köhler et al., 2010), and addition of pulverised silicate rocks to different croplands has been advocated as an effective strategy for global $\mathrm{CO}_{2}$ removal (CDR) and ameliorating ocean acidification by 2100 (Taylor et al., 2016; Beerling et al., 2018). Large-scale field trials are now in progress (http://lc $3 \mathrm{~m} .0 \mathrm{rg} /$, last access: 20 March 2020), but basic information about the way in which different microorganisms drive the sequestration processes in different soil types is still missing. Recent studies on carbonate weathering by ectomycorrhizal fungi colonising tree roots (Thorley et al., 2015) suggest that ectomycorrhizal tree species weather calcite-containing rock grains more rapidly than arbuscular mycorrhizal (AM) trees because of greater acidification by the ectomycorrhizal trees. Weathering and corresponding alkalinity export to oceans may increase with rising atmospheric $\mathrm{CO}_{2}$ (Andrews and Schlesinger, 2001) and associated climate change, slowing rates of ocean acidification.

Transfer of increasing amounts of photosynthetically derived carbon to ectomycorrhizal fungi and improved colonisation of mineral substrates during evolution of plants (Quirk et al., 2012, 2014a) are consistent with the idea that weathering of silicate minerals and sequestration of $\mathrm{C}$ into ocean carbonates has led to drawdown of global $\mathrm{CO}_{2}$ levels during the rise of ectomycorrhizal trees over the past $120 \mathrm{Myr}$ (Taylor et al., 2011; Morris et al., 2015). However, the relative constancy of atmospheric $\mathrm{CO}_{2}$ levels and absence of even further reductions over the final $24 \mathrm{Myr}$ of the Cenozoic have been attributed to a negative feedback mechanism caused by $\mathrm{CO}_{2}$ starvation (Beerling et al., 2012) that is predicted, by numerical simulations, to reduce the capacity of the terrestrial biosphere to weather silicate rocks by a factor of 4 . Differences in the magnitude of carbon transfer from plants to different types of mycorrhizal fungal symbionts and the physiological mechanisms regulating this transfer are influenced by the biotic and abiotic environment, as well as the life history and evolutionary origins of the symbiosis. Common-garden experiments (Koele et al.,2012), using sister clades of plants (with different types of mycorrhiza), might provide a suitable way of comparing functional groups, but broad generalisations should be made with extreme care since there is a high degree of context dependency (Field et al., 2017). Ericoid mycorrhizal fungi can produce copious amounts of LMW organic acids that solubilise inorganic zinc compounds (Martino et al., 2003), but there are so far no systematic studies of their role in different weathering interactions in comparison to other fungi. Further comparative studies of the role of different types of mycorrhizal symbioses in mineral weathering may shed light on the different physiological mechanisms involved. Soil microorganisms can have strong effects on plant resource partitioning and it has been shown (Ryan et al., 2012) that Kennedia species inoculated with arbuscular mycorrhizal fungi allocated lower amounts of carboxylates to the rhizosphere but had higher concentrations of $\mathrm{P}$ than non-inoculated plants, presumably using less strongly sorbed forms of $\mathrm{P}$.

Inferences about evolutionary development of weathering have been drawn using vertical scanning interferometry to study "trenching" of silicate mineral surfaces (basalt) buried under different tree species growing in an arboretum (Quirk et al., 2012) and suggest that trenching and hyphal colonisation increase with evolutionary progression from AM fungi to ectomycorrhizal fungi, and with progression from gymnosperm to angiosperm host plants. It is suggested that this evolutionary progression resulted in release of calcium from basalt by ectomycorrhizal gymnosperms and angiosperms at twice the rate achieved by AM gymnosperms and that forested ecosystems have become major engines of continental silicate weathering, regulating global $\mathrm{CO}_{2}$ concentrations by driving calcium export into ocean carbonates (Quirk et al., 2012) (Fig. 4). Additional laboratory studies of the same tree species using different $\mathrm{CO}_{2}$ environments suggest that weathering intensified during evolutionary progression from AM fungal symbionts to ectomycorrhizal symbionts and that calcium dissolution rates were related to photosynthate energy fluxes and higher during a simulated past $\mathrm{CO}_{2}$ atmosphere (1500 ppm) under which ectomycorrhizal fungi evolved (Quirk et al., 2014b).

\section{Summary}

Microorganisms have interacted with minerals for billions of years, enriching the atmosphere with oxygen and shaping the evolution of minerals long before the evolution of land plants. There is strong evidence that the plastids of algae and higher plants evolved from free-living bacteria through endosymbiosis, and plants have continued to evolve in conjunction with microorganisms through symbiotic alliances (mycorrhiza, actinorhiza, rhizobia, plant-growth-promoting rhizobacteria (PGPR), etc.) such that they are really holobionts - assemblages of organisms. This enabled the holobionts to become successively more efficient biogeochemical engineers. Hypotheses have been advanced concerning the 
evolutionary development of weathering and differing contributions of different types of mycorrhizal symbiosis. Further advances in understanding will require more studies of different combinations of plant and fungal species, accompanied by rigorous, DNA-based, in situ identification of the different fungal symbionts. However, the magnitude of carbon transfer to different types of mycorrhizal fungal symbionts and the physiological mechanisms regulating this transfer are highly context dependent, and advances in knowledge will require sound ecological understanding, based on integration of a diverse array of biotic and abiotic factors. Better information is still required on the identity of bacteria and fungi colonising bedrock outcrops and other mineral substrates in forests. The diversity of these communities is high and it is important to identify the particular taxa that are most active in competing for plant-derived $\mathrm{C}$ and to identify the amounts and chemical forms in which it is delivered to mineral surfaces. Use of ${ }^{13} \mathrm{C}$-based stable isotope probing is likely to be helpful in identifying the most active taxa delivering plantderived $\mathrm{C}$ to mineral surfaces. Analysis of the chemical composition of compounds involved will necessitate further studies using nanoSIMS, NMR and Fourier transform infrared (FTIR) spectroscopy. Improved understanding of weathering at an ecological level requires better knowledge about the processes involved in sequestration of atmospheric $\mathrm{CO}_{2}$, and further investigation of the forms in which $\mathrm{C}$ is sequestered during weathering in forests is necessary. Weathering processes are impacted by different environmental conditions and types of forest management and further studies are required to investigate how these are impacted by changes in atmospheric $\mathrm{CO}_{2}$ concentration and effects of $\mathrm{N}$ deposition and fertilisation.

\section{Methods using stable isotopes}

Stable isotopes, especially of $\mathrm{Ca}$ and $\mathrm{Sr}$, have been used extensively to source the origin of $\mathrm{Ca}$ in drainage water; when applied to plant tissues, they can be used to trace plant nutrients back to their primary source. Isotope tracing has been mostly used to study apatite weathering. P has no stable isotopes, and the mobilisation and uptake dynamics of apatite can therefore only be studied via the $\mathrm{Ca}$ ion (or potentially the ${ }^{18} \mathrm{O} /{ }^{16} \mathrm{O}$ in the phosphate group). In most rocks and soils, apatite is the sole primary $\mathrm{P}$ source. However, its contribution to the soil solution Ca pool is minor compared with other minerals. If the $\mathrm{Ca}$ isotope ratio in the plant is more similar to the signature in apatite than to the signature in the soil solution, then it indicates that the plant directly acquires $\mathrm{Ca}$ from apatite. Blum et al. (2002) applied this technique to a temperate mixed forest using $\mathrm{Ca}: \mathrm{Sr}$ ratios in soil water, minerals in the soil, and different mycorrhizal and non-mycorrhizal trees. The authors concluded that direct calcium uptake by ectomycorrhizal fungi weathering apatite in the parental material could compensate for calcium loss in base-poor ecosys- tems. Data on element ratios should, however, be interpreted with care because of high variation in $\mathrm{Ca}: \mathrm{Sr}$ ratios in different plant tissues and limited understanding of the cycling of these elements in plants (Watmough and Dillon, 2003), as well as contradictory data of Dijkstra and Smits (2002) (see below) that suggest the conclusion of Blum et al. (2002) is overstated. Field studies using mesh bags containing microcline and biotite, buried in Swedish Picea abies forests (Wallander et al., 2006), used the ${ }^{87} \mathrm{Sr}:{ }^{86} \mathrm{Sr}$ ratio to calculate the fraction of $\mathrm{Sr}$ in the mycorrhizal root tips that had originated from the minerals. Although the total amounts of $\mathrm{Sr}$ released from the minerals could not be calculated since the total plant biomass enriched with ${ }^{87} \mathrm{Sr}$ was unknown, the study clearly demonstrates the potential of ectomycorrhizal fungi to mobilise and take up nutrients such as $\mathrm{Ca}$ and $\mathrm{K}$ from microcline and biotite under field conditions.

In many forest ecosystems, plant-available pools of $\mathrm{Mg}$, $\mathrm{Ca}$ and $\mathrm{K}$ are assumed to be stored in the soil as exchangeable cations adsorbed on the cation exchange complex (exchangeable pools). However, other storage forms of $\mathrm{Mg}, \mathrm{Ca}$ and $\mathrm{K}$ that have not been fully characterised may play an important role in plant nutrition and biogeochemical cycles and be plant-available on very short timescales $(<1 \mathrm{~d})$. Isotopic dilution techniques using the stable isotopes ${ }^{26} \mathrm{Mg},{ }^{44} \mathrm{Ca}$ and ${ }^{41} \mathrm{~K}$ have been developed (van der Heijden et al., 2018) to trace and quantify the pools of $\mathrm{Mg}$, $\mathrm{Ca}$ and $\mathrm{K}$ (isotopically exchangeable pools) that contribute directly to equilibrium processes between the soil water and the soil in a hardwood forest. These show that isotopically exchangeable pools of $\mathrm{Mg}$, $\mathrm{Ca}$ and $\mathrm{K}$ are greater than traditionally measured exchangeable pools. Storage forms of $\mathrm{Mg}, \mathrm{Ca}$ and $\mathrm{K}$ in the isotopically exchangeable pool could include chelation with soil organic matter, retention on soil aluminium and iron oxides and hydroxides through phosphate, and/or organic acid bridges and site-specific adsorption. The isotopic dilution method is a relevant tool to quantify the plant-available pools of $\mathrm{Mg}$, $\mathrm{Ca}$ and $\mathrm{K}$ on short timescales (source and sink pools) and is a very promising approach to characterise and quantify the processes responsible for the depletion and/or replenishment of these pools over longer timescales.

Field studies of small rock fragments isolated from a Finnish $P$. sylvestris forest with Tricholoma matsutake fruiting bodies (Vaario et al., 2015) revealed the presence of $T$. matsutake on $97 \%$ of the rock fragments, and laboratory assays using X-ray diffraction confirmed the ability of the fungus to absorb some trace elements directly from the rock fragments, but uptake of $\mathrm{Mg}$ and $\mathrm{K}$ did not appear to be significant. In contrast, laboratory studies of the capacity of different fungi to mobilise $\mathrm{P}$ and base cations from granite particles (conducted within QWARTS) (Fahad et al., 2016) suggest that some ectomycorrhizal fungi can mobilise and accumulate significantly higher concentrations of $\mathrm{Mg}, \mathrm{K}$ and $\mathrm{P}$ than non-mycorrhizal fungi. The mycorrhizal fungi can fractionate $\mathrm{Mg}$ isotopes, discriminating against heavier isotopes, and we found a highly significant inverse relationship be- 
tween $\delta^{26} \mathrm{Mg}$ tissue signatures and mycelial concentration of $\mathrm{Mg}$ (Fig. 5). This provides a theoretical framework for testing hypotheses about fungal weathering of minerals in future experiments. If active mobilisation and uptake of lighter ${ }^{24} \mathrm{Mg}$ isotopes results in relative enrichment of heavy $\mathrm{Mg}$ isotopes left in soil solution and soil, this should be evident in areas of active weathering. Mesocosm experiments, conducted within the QWARTS project, employing a gradient of increasing organic matter depletion to simulate progressively more intense forest biomass harvesting, revealed significant and successive enrichment of ${ }^{26} \mathrm{Mg}$ signatures in the soil solution in the $\mathrm{B}$ horizon, associated with increased availability of organic matter and resultant increases in plant and fungal biomass (Fig. 6). No such enrichment was found in other horizons or in systems without plants (and therefore without mycorrhizal fungi). This suggests that significant biological weathering of $\mathrm{Mg}$ takes place in the B horizon, driven by higher plant biomass that enables improved carbon allocation to the fungal mycelium and also constitutes a larger sink for uptake of mobilised base cations. Although the experiments provide strong support for the idea of biologically driven mobilisation of $\mathrm{Mg}$ from B-horizon mineral soil, the process was not sufficient to maintain optimal tree growth in systems with a severely reduced organic matter pool. In addition, studies carried out under both field and laboratory conditions show that $\mathrm{Mg}$ isotope fractionations are controlled by the same biological factors in the critical zone, defined as the outer layer of earth from vegetation to the soil. Silicate rocks show a relatively small range of variation in $\mathrm{Mg}$ isotopic ratios (denoted as $\delta^{26} \mathrm{Mg}$ ) (Bolou-Bi et al., 2009; Shen et al., 2009; Uhlig, et al., 2017). During the weathering of these rocks at the watershed level, it was revealed that isotopic fractionation of $\mathrm{Mg}$ isotopes was in favour of light isotopes in soil solution, while the soils were enriched in heavy isotopes (Pogge von Strandmann et al., 2008; Tipper et al., 2010). Studies conducted in forest ecosystems (Bolou-Bi et al., 2012; Mavromatis et al., 2014; Uhlig et al., 2017) indicate variation in soil solution signatures of surface soil layers, suggesting a role of vegetation through the $\mathrm{Mg}$ isotope cycle (uptake and litterfall), soil exchangeable fraction and rainwater, and light $\mathrm{Mg}$ isotope return via litterfall. In deeper soil horizons, however, the soil solution signatures may be the result of two additional processes: (a) the mineral dissolution leaching the light isotope into solution and subsequently weathered minerals being systematically enriched in heavy $\mathrm{Mg}$ isotopes relative to fresh rock, and (b) clay formation and/or $\mathrm{Mg}$ adsorption removing the heavy $\mathrm{Mg}$ isotope from soil solution (Huang et al., 2012; Opfergelt et al., 2014). $\mathrm{Mg}$ isotope fractionation has also been observed under laboratory conditions during the dissolution of primary minerals (Wimpenny et al., 2010).

In studies of $\mathrm{Ca}$ isotope cycling in a forest ecosystem, it appears that the soil solution and exchangeable fraction generally display enrichment in the heavy isotope compared to soil particles, bedrock and rainwater (Holmden and Bélanger,

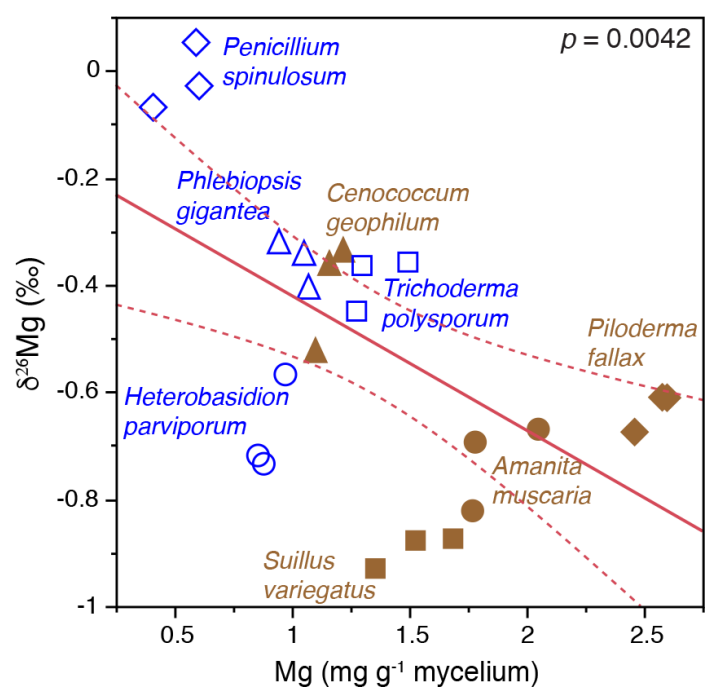

Figure 5. Bivariate plots of $\delta^{26} \mathrm{Mg}(\%$ ) versus $\mathrm{Mg}$ concentration $\left(\mathrm{mg} \mathrm{g}^{-1}\right)$ in mycelia of ectomycorrhizal and nonmycorrhizal fungi grown on mineral-free modified Melin-Norkrans (MMN) medium amended with granite particles. The fungi were grown on cellophane membranes covering the growth substrates in Petri dish microcosms. Open blue symbols represent nonmycorrhizal fungi and closed brown symbols represent ectomycorrhizal fungi. (Figure is reproduced with permission; Fahad et al., 2016.)

2010; Hindshaw et al., 2011). However, the soil solution isotope signatures are not the simple result of weathering processes in soils because the congruent dissolution of rock or mineral observed in lab and field conditions did not cause any measurable $\mathrm{Ca}$ isotope fractionation (Hindshaw et al., 2011; Ryu et al., 2011; Cobert et al., 2011). This suggests that another process, such as the preferential uptake of the light $\mathrm{Ca}$ isotope $\left({ }^{40} \mathrm{Ca}\right)$ by vegetation, decreases the soil solution $\mathrm{Ca}$ isotope ratio in the upper horizon in addition to light $\mathrm{Ca}$ isotope return via litterfall (Page et al., 2008; Holmden and Bélanger, 2010). In deeper soil horizons, soil solution $\delta^{44 / 40} \mathrm{Ca}$ may result from the dissolution of minerals such as apatite. Interestingly, experiments by Dijkstra and Smits (2002) indicate that most of the Ca taken up by trees comes from litter recycling. In a comparable mixed forest, also in the north-eastern United States, the annual $\mathrm{Ca}$ import from weathering in the rooting zone is less than $0.3 \%$ of the annual Ca uptake, which was a flux 4-fold smaller than the annual atmospheric deposition (Dijkstra and Smits, 2002). Inputs of nutrients such as $P$, from atmospheric deposition, may also be significant in coastal Fynbos systems (Brown et al., 1984) and the Florida everglades (Redfield et al., 2002). However, the data from our QWARTS experiments suggest that mobilisation of Mg may function differently in boreal coniferous forests, with higher amounts being mobilised from inorganic substrates in the B horizon.

Mycorrhizal fungi play a central role in mobilising $\mathrm{N}$ and $\mathrm{P}$ from organic substrates, and when these are depleted $\mathrm{N}$ 
and $\mathrm{P}$ limit tree growth, resulting in reduced $\mathrm{C}$ supply to the mycorrhizal mycelium and reduced capacity for mobilisation of base cations from the mineral horizons. Although mobilisation of $\mathrm{Mg}$ from the $\mathrm{B}$ horizon was sufficient to support increased biomass production in systems supplied with extra organic material (Fig. 6), it was not sufficient to compensate for losses of base cations when organic material was most depleted. The results of these experiments are therefore consistent with the predictions of modelling that, under intensive forestry with removal of organic residues, base cation supply will not be sustainable in the long term. Intensive, sustained harvesting of biomass may lead to $\mathrm{N}$ limitation before base cations become limiting. Applications of different fertilisers (Xiao et al., 2017) or inadvertent $\mathrm{N}$ deposition (Averill et al., 2018) may have negative effects on both weathering and $C$ sequestration.

Smits and Wallander (2017) advocate detailed studies of the liquid chemistry of local weathering sites at the micrometre scale, together with upscaling to soil-scale dissolution rates. The authors suggest that future research should focus on whole ecosystem dynamics, including the behaviour of soil organic matter, and that early-stage primary succession ecosystems on low reactive surfaces, such as fresh granites, should be included. Smits and Wallander (2017) also recommend the use of stable isotopes by choosing minerals and soils with distinct isotope ratios.

\section{Summary}

Experiments using stable isotopes have the potential to improve understanding of the roles played by different groups of microorganisms in biological weathering. In vitro studies of base cation mobilisation from granite particles so far suggest that symbiotic mycorrhizal fungi may be more efficient at mobilising $\mathrm{Mg}, \mathrm{K}$ and $\mathrm{P}$ than saprotrophic fungi, but it is necessary to test a wider range of species before such broad conclusions can be drawn. Care should also be exercised in interpreting experiments conducted in vitro in the absence of host plants, since these provide important sinks for mobilised nutrients that could otherwise retard weathering reactions should they accumulate. Fractionation of stable $\mathrm{Mg}$ isotopes by mycorrhizal fungi, with preferential uptake of lighter isotopes, results in enriched levels of ${ }^{26} \mathrm{Mg}$ in soil solution, and laboratory experiments with reconstructed podzol profiles have demonstrated that this enrichment occurs primarily in the B horizon. The data suggest that this pathway may be of significance in the field but reductions in (Ncontaining) organic matter resulted in reduced tree growth and reduced $\mathrm{Mg}$ uptake, suggesting that increased biological weathering of $\mathrm{Mg}$ is unlikely to compensate for losses of $\mathrm{Mg}$ through organic matter removal if $\mathrm{N}$ is also limiting. However, $\mathrm{K}$ and $\mathrm{P}$ were also deficient in this experiment so conclusions should be drawn with care. Similar experiments with isotopes of other elements may reveal wider information about patterns of nutrient uptake. In addition to their possible weathering effects, mycorrhizal fungi play important roles in $\mathrm{N}$ acquisition from organic substrates, illustrating how decomposition and weathering are intercoupled.

\section{Modelling of biological weathering in forest soils}

\subsection{Developments and improvements in modelling biological weathering}

Models greatly improve our ability to quantify weathering rates and how they change over time. Akselsson et al. (2019) present an extensive review of methods for estimating weathering rates in forest soils. These range from mass-balance budget calculations (e.g. Simonsson et al., 2015) and gravimetric approaches (Turpault et al., 2009) to the depletion method based on the elemental concentration differences between weatherable and unweatherable minerals (such as zirconium bound in zircon or titanium in rutile) (Stendhal et al., 2013) to dynamic models based on the transition state theory (Erlandsson et al., 2016). These methods address, in different ways, the role of biological processes in weathering (Rosling et al., 2009). Here we attempt to describe the major approaches to implementing important biological processes into weathering rate estimates over the last decade.

Catchment and ecosystem mass-balance approaches have been widely employed to estimate mineral weathering rates (Price et al., 2013, Hartmann and Moosdorf, 2011). Application of machine learning approaches (Povak et al., 2014) can further increase the utility of mass-balance approaches for evaluating the potential importance of different processes to weathering rates. Biomass accumulation emerges, in many simulations (Wilcke et al., 2017; Zetterberg et al., 2016), as a key variable in mass-balance estimates of mineral weathering and a major source of uncertainty (Simonsson et al., 2015; Zetterberg et al., 2016). Furthermore, the derivative nature of the mass-balance approach reduces its value for assessing the mechanisms that control weathering rates, reducing their suitability to predict future weathering rates under changing conditions.

Taylor et al. (2011) built on a geochemical model developed by Banwart et al. (2009), which attempts to quantify the contribution of biologically derived protons and ligands to mineral weathering rates and distinguishes between vegetation that forms arbuscular (AM) mycorrhizal associations and vegetation that forms ectomycorrhizal (EM) associations. Their model assumes that AM fungi do not exude significant amounts of organic acids while EM fungi do, and it models the activity of that exudation as that of oxalic acid. They also divide the soil volume into an area of immediate proximity to mycorrhizal hyphae, the mycorrhizosphere and the bulk soil. When they applied their model over the last $200 \mathrm{Myr}$ they observed that the drawdown of global atmospheric $\mathrm{CO}_{2}$ levels over the last $120 \mathrm{Myr}$ could largely be attributed to the emergence and diversification of 
(a)

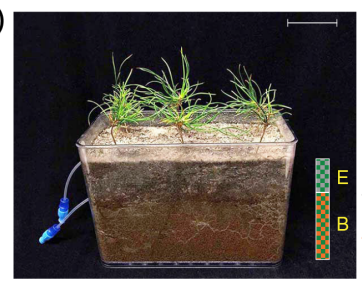

(b)

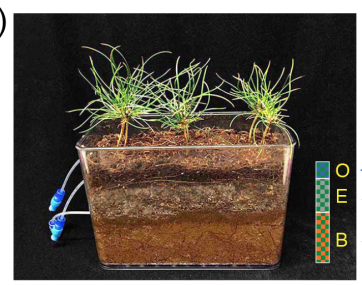

(c)
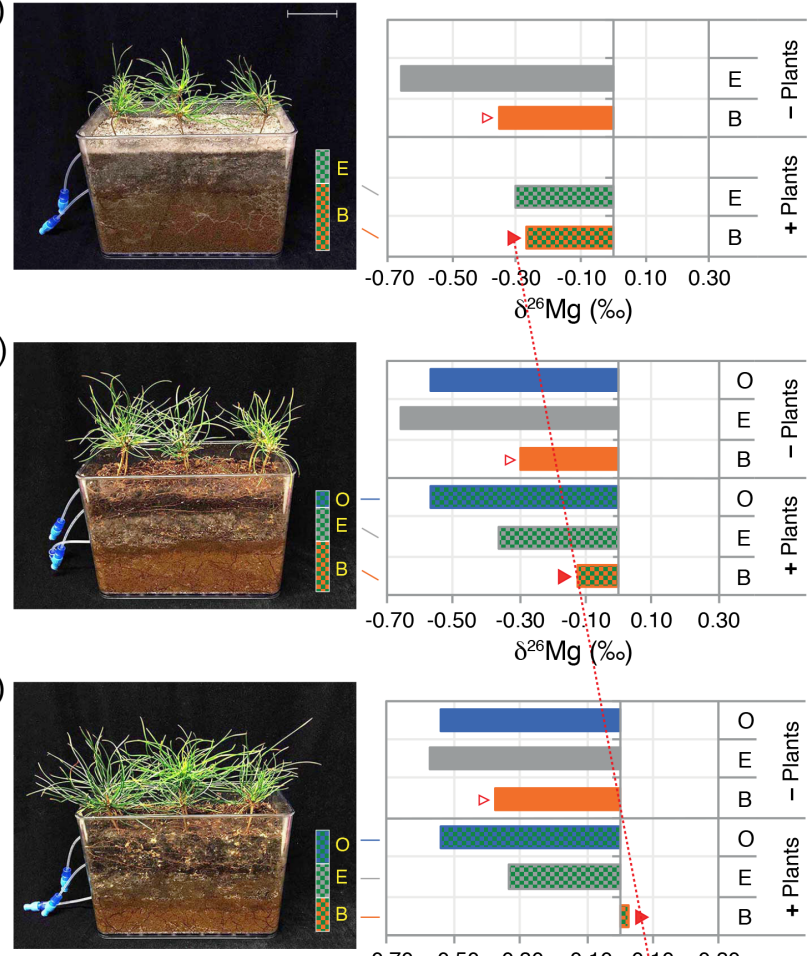

$\delta^{26} \mathrm{Mg}(\%)$
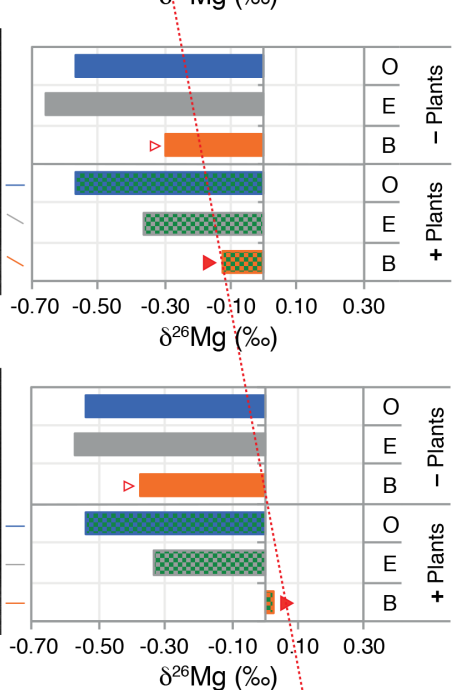

(d)
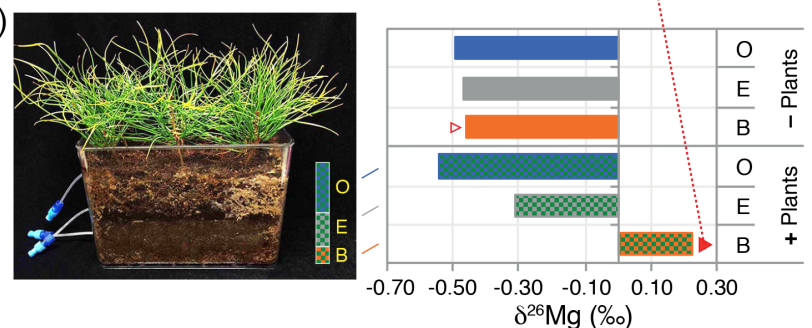

Figure 6. Mesocosms containing reconstructed podzol soil profiles with different amounts of organic (O) horizon material to simulate different intensities of forest harvesting. (a) No O horizon; (b) $50 \%$ thickness O horizon; (c) normal (100\%) thickness O horizon; (d) $150 \%$ thickness O horizon. The histograms show levels of enrichment of ${ }^{26} \mathrm{Mg}$ in soil solution extracted from the $\mathrm{O}$ (organic), $\mathrm{E}$ (eluvial) and B (illuvial) horizons. The upper part of each diagram represents systems incubated without plants, the lower part of each diagram represents systems containing Pinus sylvestris seedlings (as illustrated). Note that the seedling growth is proportional to the amount of organic soil, from which ectomycorrhizal fungi mobilise $\mathrm{N}$. The enrichment of ${ }^{26} \mathrm{Mg}$ in the soil solution becomes greater and greater with increasing plant growth (and therefore increasing $\mathrm{Mg}$ uptake) - but only in the B horizon, because there is discrimination against uptake of the heavy isotope. This suggests that the B horizon is the primary site of active mineral weathering and Mg uptake. Extensive colonisation of roots and organic and mineral substrates by ectomycorrhizal mycelia is visible. Horizontal scale bar in (a) is equal to $5 \mathrm{~cm}$. angiosperms and the spread of EM fungi. However, in addition to organic acid exudation, hyphal length density, which defined the volume of the mycorrhizosphere, was parameterised to be 25-fold greater in EM-dominated ecosystems than AM-dominated systems. Modelled soil chemistry and the resulting terrestrial carbon sink were also highly sensitive to hyphal length density. Taylor et al. (2012) further developed this weathering model based on mycorrhizal association type and coupled it to a dynamic global vegetation model and validated it against a global dataset of watershed flux data. The resulting model, when applied over the last $200 \mathrm{Myr}$, indicated that biological weathering was stronger in the distant past than today and estimated that vegetation and mycorrhizal fungi have increased terrestrial weathering rates by a factor of 2 . While their model performed reasonably well in the validation across a global series of catchment data, their findings did not support a distinct dichotomy in weathering behaviour between AM-dominated and EM-dominated ecosystems. Quirk et al. (2014a) build on the model developments of Taylor et al. $(2011,2012)$ to illustrate the potential for a feedback between atmospheric $\mathrm{CO}_{2}$ levels and biological weathering rates, such that, as $\mathrm{CO}_{2}$ levels increase, global plant productivity and autotrophic soil inputs of protons and organic acids do so as well, stimulating biological weathering and serving as a negative feedback to increasing $\mathrm{CO}_{2}$ levels. As $\mathrm{CO}_{2}$ levels decrease, so does biological weathering. This sequence of models develops hypotheses concerning the role of land plants in the geology of earth and the global biogeochemical carbon cycle, with a framework to account for differential biological weathering activity by distinct vegetation types. While considerable evidence exists pointing to the potential for ectomycorrhizal fungi to be more potent weathering agents than AM fungi, field studies comparing weathering rates in paired AM- and EM-dominated forests have failed to find significant differences in mineral weathering rates (Koele et al., 2014; Remiszewski et al., 2016). Future applications utilising rhizosphere or mycorrhizosphere vs. bulk soil volumes should place more emphasis on the choice of hyphal length densities and should likely use functions, as opposed to fixed parameters, that depend on plant type as well as plant productivity and nutrient status to describe fineroot and mycorrhizal hyphal root lengths.

Roelandt et al. (2010) coupled a reactive transport model to the Lund-Potsdam-Jena global dynamic vegetation model, which they termed Biosphere-Weathering at the Catchment Scale (B-WITCH), and were able to model base cation efflux accurately from the Orinoco watershed. They concluded that vegetation exerts a major role on mineral weathering rates but that this role is primarily hydrological, via evapotranspiration fluxes. However, while their model did feature organic ligand-promoted dissolution, the source of those ligands was decomposition only, and they treat the entire rooting zone as a single interconnected solution. Furthermore, they do feature plant functional types, those functional types do not correspond to below-ground physiology or mycorrhizal associa- 
tion. The B-WITCH model appears to reflect the most mechanistic approach amongst global dynamic vegetation models to estimating mineral weathering rates, but additional processes may need to be implemented to capture the influence of biology on mineral weathering rates.

Maher et al. (2010) applied the reactive transport geochemical model CrunchFlow, which estimates weathering rates based on experimentally derived dissolution equations for individual minerals, to examine the effect of fluid residence time, which in turn controls the transport of weathering products away from mineral surfaces, on mineral weathering rates. They observed a strong inverse relationship between fluid residence time and weathering rates and interpreted this as clear evidence for transport control of weathering rates in natural ecosystems. Lawrence et al. (2014) coupled an organic acid module to the CrunchFlow model to examine the potential role of organic acids, modelled as oxalic acid, on mineral weathering rates. They observed that the primary effect of oxalic acid was to increase soluble Al but decrease free $\mathrm{Al}^{3+}$ concentrations in solution; mineral weathering was enhanced near the zone of oxalic acid production (the topsoil) but decreased further down the profile. The description of organic acid levels as the product of production and decomposition processes and the geochemical description of ligand-promoted chelation, dissolution and transport may be useful to model the effects of biological exudates on mineral weathering rates and adaptable across a range of models. Winnick and Maher (2018) developed CrunchFlow to examine the dependence of mineral weathering rates on gaseous and dissolved $\mathrm{CO}_{2}$ concentrations and observed a very strong relationship between weathering rates and soil $\mathrm{CO}_{2}$. They further suggested that this may be an important mechanism by which soil respiration of vegetation (and mycorrhizal fungi) may stimulate mineral weathering.

Mineral weathering is dynamically simulated in the PROFILE and ForSAFE models, which have been widely used for unsaturated soils (for recent examples see Akselsson et al., 2016; Erlandsson et al., 2016; Belyazid et al., 2019; Phelan et al., 2014). In ForSAFE, tree cover, soil microbes and related biological processes are also integrally simulated. Trees are assumed to affect weathering through a number of causal pathways. Firstly, trees have a direct negative influence on soil moisture through transpiration. The consequent reduction in soil moisture limits weathering, as the latter is directly dependent on wetted mineral surface area. Water uptake also leads to an increase in element concentrations, drawing the soil solution closer to saturation and acting as a retarding brake on weathering (Erlandsson et al., 2016). Secondly, nutrient uptake reduces the concentration of base cation weathering products, releasing these brakes and thereby promoting weathering rates. Thirdly, plants are responsible for the production of organic matter, which, through below-ground allocation and litter fall, feeds soil organic carbon, dissolved organic carbon and $\mathrm{CO}_{2}$ concentrations. Both organic radicals and higher soil $\mathrm{CO}_{2}$ pressure have positive influences on weathering rates. At the same time, the mineralisation of litter also releases the base cations, thus increasing element concentrations and thereby slowing down weathering rates. Fourthly, plants have a direct effect on soil solution proton concentration, which promotes higher mineral weathering. Plants can lower $\mathrm{pH}$ through the production of organic matter, but most importantly through the uptake of positively charged cations and release of protons to counterbalance charge. Lower $\mathrm{pH}$ promotes higher weathering rates but also the solubility of aluminium ions whose higher concentrations act as weathering brakes. The net effect on weathering, i.e. the balance between the positive effect from lower $\mathrm{pH}$ and the negative from higher aluminium concentrations, may differ depending on soil properties. The contribution of biological weathering may be improved by division of the soil volume into rhizosphere or mycorrhizosphere and bulk soil portions. Process descriptions of root and hyphal influence on the solution and surface chemistry within the rhizosphere and/or mycorrhizosphere could also be improved. Division of DOC into discrete chemical functional classes (promoting vs. inhibitory, actively exuded vs. incomplete decomposition products) could increase our understanding of the influence of ligand promotion or inhibition of weathering rates.

\subsection{Research priorities for modelling biological weathering}

Based on the preceding sections, we have identified five biological processes that can be incorporated into models quantifying soil mineral weathering rates, to make them more mechanistic and useful as predictive tools:

- exudation of LMW ligands promoting weathering;

- nutrient uptake rates as a driver of weathering reactions;

- the concentration effect of biofilms on weatheringpromoting ligands and protons;

- the dependence of the above process on particular microbial and plant assemblages, including mycorrhizal type;

- the dependence of the above processes on carbon flux from autotrophs, and the sensitivity of this to water and nutrient availability.

The stimulatory effect of particular LMW organic acids and siderophores on soil mineral weathering rates is a function of both exudation rate and biological degradation rates of the same compounds. The chemical composition of soil water DOC and exudates exerts considerable control on the degree of stimulation, or, potentially, inhibition of weathering rates. Modelling ligand-promoted dissolution as a function of total DOC without consideration of DOC character may lead to inaccurate interpretations of mineral dissolution rates derived 
from experiments with specific organic species but should, with better data, open the door for more complex descriptions of soil solutions and their effects on mineral weathering rates.

Geochemical weathering models require the incorporation of mechanisms (either through equilibrium equations or inhibitory factors) that allow the build-up of weathering products to slow weathering rates. The treatment of soil solution fluxes should allow for accumulation and removal of weathering products in soil microenvironments (such as around mineral surfaces and mycelia), as bulk soil solution data may not capture the concentration gradients found around mineral surfaces. The observation, across a variety of both empirical studies and modelling approaches, that nutrient uptake into vegetation is a major driver of weathering rates should continue to drive research into the effects of soil solution concentrations near mineral surfaces, and their deviation from bulk soil solution, as a factor controlling dissolution rates. Ongoing research into the extent and chemistry of microbial biofilms in soils, aided by technological developments in microprobes and spectroscopy, is giving an increased understanding of their importance and extent in the soil for controlling the solution chemistry at mineral surfaces, which may lead to incorporation into models.

The dependence of biological weathering on particular microbial and plant assemblages, in particular the mycorrhizal type, has not yet been determined and requires further detailed studies of the specificity of ectomycorrhiza-bacteria interactions and the physiological differences between different bacteria and fungi in their ability to promote dissolution of different minerals. A growing consensus on the importance of root length density and hyphal length density as important explanatory factors governing biological process rates may lead to increased inclusion of them as factors or parameters in future models. Further information is also required on the variation in carbon flux from autotrophs to different fungal and bacterial components of biofilms in contact with different minerals and the sensitivity of this carbon flux to differences in water and nutrient availability. A major area of model development has been in global plant productivity, not least because of its central role in the carbon cycle. Advances in describing below-ground allocation (as opposed to above-ground) have lagged far behind but are now increasing rapidly, and this should provide valuable data to improve model descriptions of biological weathering processes.

\section{Conclusions}

In this paper we attempt to outline the consequences of interactions between minerals, microorganisms and plants at different spatial scales and to review the influence of biological processes on mineral weathering within an evolutionary context. The interaction of microorganisms with rocks and minerals took place for 3.5 billion years before the appearance of the first land plants and there is documented evi- dence that early microorganisms had wide-ranging effects on both chemical and biological processes (Fig. 3), including (a) the accumulation of oxygen in the atmosphere, and the evolution of over two thirds of the minerals that exist today and (b) the evolution of plastids through serial endosymbiosis. The subsequent evolution of higher plants made possible by efficient photosynthesis and successive increases in their size, nutrient acquisition and ability to colonise and allocate photosynthetically derived carbon to mineral (and organic) substrates, has enabled them to have increasing influence as biogeochemical engineers (Fig. 3c-g). Microbial symbionts have played an integral part in the evolution of plants and their ability to capture growth-limiting nutrients such as $\mathrm{N}$ (Moreau et al., 2019). The influence of vegetation on mineral substrates is almost axiomatic but quantification of the contribution of plant-associated microorganisms to mineral weathering is problematical for two reasons. Firstly, the ubiquitous distribution of microorganisms, the fact that plants devoid of microorganisms do not exist under natural conditions, means that plants need to be considered from a more holistic perspective, as holobionts, together with the many different microorganisms associated with them. Secondly, processes occurring at small spatial scales are difficult to quantify and upscale to the catchment, ecosystem or global scale. Although the combined effects of plants and their microbial symbionts have quantifiable effects on mineral dissolution and capture of nutrients, continued effort must be directed at elucidating the identity, distribution and functional characteristics of these many different microbial taxa. Sverdrup (2009) acknowledged the importance of "biologically induced systemic effects" on weathering and concluded that "the growth of the trees and forest growth represents the largest single biological process that can affect weathering, followed closely by decomposition of organic matter'. Boreal and temperate forest ecosystems are characterised by ubiquitous symbiotic associations with ectomycorrhizal fungi, and the central axiom of the current paradigm of ectomycorrhizal functioning is that these systems have evolved to promote tree growth through efficient uptake of nutrients, in particular through mobilisation of $\mathrm{N}$ via decomposition of organic substrates (Lindahl and Tunlid, 2015; Nicolás et al., 2019). Ectomycorrhizal fungi are therefore very likely to influence mineral weathering directly or indirectly, and additional information about their direct interactions with mineral substrates and likely responses to different types of environmental stresses, including those induced by forest management practices, is an important research priority. Weathering of minerals is important not just with respect to the sustainability of forestry. It is evident that the global weathering engine has had longterm effects on atmospheric $\mathrm{CO}_{2}$ levels. Long-term stabilisation of $\mathrm{C}$, derived from the atmosphere, in organic and mineral substrates, may take place through interactions involving glycoproteins, melanin, extracellular polymeric substances, and formation of secondary minerals and mineraloids. Better understanding of these processes may facilitate improved 
forestry management practices that not only ensure sustainable production of biomass but can also be integrated into new carbon dioxide reduction technologies.

Data availability. Further details of data presented in Fig. 5 are available at https://doi.org/10.1111/1758-2229.12459 and sequences of the identified fungi are deposited in GenBank under the accession numbers KX451146 and KX451147.

Author contributions. RDF wrote most parts of the paper but with suggestions and inputs from AR, KB and BL. NR, SB and SJK, in particular, wrote most of the section on modelling, and EBB and HW provided substantial input to the section on stable isotopes. SM provided substantial input to Figs. 5 and 6 . The work described in Figs. 5 and 6 was carried out by SM and ZF with advice from SJK. EBB carried out the stable isotope analyses in these experiments.

Competing interests. The authors declare that they have no conflict of interest.

Special issue statement. This article is part of the special issue "Quantifying weathering rates for sustainable forestry (BG/SOIL inter-journal SI)". It is not associated with a conference.

Financial support. This research was supported by FORMAS, Swedish Research Council for Sustainable Development (grant nos. 2011-1691, 2014-01272 and 2017-00354).

Review statement. This paper was edited by Nobuhito Ohte and reviewed by three anonymous referees.

\section{References}

Ahmed, E. and Holmström, S. J. M.: Siderophores in environmental research: roles and applications, Microb. Biotechnol., 7, 196208, 2014.

Ahmed, E. and Holmstrom, S. J. M.: Microbe-mineral interactions: The impact of surface attachment on mineral weathering and element selectivity by microorganisms, Chem. Geol., 403, 13-23, 2015.

Ahonen-Jonnarth, U., Van Hees, P. A. W., Lundstrom, U. S., and Finlay, R. D.: Organic acids produced by mycorrhizal Pinus sylvestris exposed to elevated aluminium and heavy metal concentrations, New Phytol., 146, 557-567, 2000.

Akselsson, C., Westling, O., Sverdrup, H., and Gundersen, P.: Nutrient and carbon budgets in forest soils as decision support in sustainable forest management, Forest Ecol. Manag., 238, 167174, 2007.

Akselsson, C., Olsson, J., Belyazid, S., and Capell, R.: Can increased weathering rates due to future warming compensate for base cation losses following whole-tree harvesting in spruce forests?, Biogeochemistry, 128, 89-105, 2016.

Akselsson, C., Belyazid, S., Stendahl, J., Finlay, R., Olsson, B. A., Erlandsson Lampa, M., Wallander, H., Gustafsson, J. P., and Bishop, K.: Weathering rates in Swedish forest soils, Biogeosciences, 16, 4429-4450, https://doi.org/10.5194/bg-16-44292019, 2019.

Allen, J. F.: A proposal for formation of Archaean stromatolites before the advent of oxygenic photosynthesis, Front. Microbiol., 7, 1784, https://doi.org/10.3389/fmicb.2016.01784, 2016.

Almeida, J. P., Rosenstock, N. P., Forsmark, B., Bergh, J., and Wallander, H.: Ectomycorrhizal community composition and function in a spruce forest transitioning between nitrogen and phosphorus limitation, Fungal. Ecol., 40, 20-31, 2019.

Andrews, J. A. and Schlesinger, W. H.: Soil $\mathrm{CO}_{2}$ dynamics, acidification, and chemical weathering in a temperate forest with experimental $\mathrm{CO}_{2}$ enrichment, Global Biogeochem. Cy., 15, 149-162, 2001.

Archibald, J. M.: Genomic perspectives on the birth and spread of plastids, P. Natl. Acad. Sci. USA, 112, 10147-10153, 2015.

Averill, C., Dietze, M. C., and Bhatnagar, J. M.: Continental-scale nitrogen pollution is shifting forest mycorrhizal associations and soil carbon stocks, Glob. Change Biol., 24, 4544-4553, 2018.

Bahr, A., Ellstrom, M., Bergh, J., and Wallander, H.: Nitrogen leaching and ectomycorrhizal nitrogen retention capacity in a Norway spruce forest fertilized with nitrogen and phosphorus, Plant Soil, 390, 323-335, 2015.

Balogh-Brunstad, Z., Kent Keller, C., Thomas Dickinson, J., Stevens, F., Li, C. Y., and Bormann, B. T.: Biotite weathering and nutrient uptake by ectomycorrhizal fungus, Suillus tomentosus, in liquid-culture experiments, Geochim. Cosmochim. Ac., 72, 2601-2618, 2008.

Banfield, J. F., Barker, W. W., Welch, S. A., and Taunton, A.: Biological impact on mineral dissolution: application of the lichen model to understanding mineral weathering in the rhizosphere, $\mathrm{P}$. Natl. Acad. Sci. USA, 96, 3404-3411, 1999.

Banwart, S. A., Berg, A., and Beerling, D. J.: Process-based modeling of silicate mineral weathering responses to increasing atmospheric $\mathrm{CO}_{2}$ and climate change, Global Biogeochem. Cy., 23, GB4013, https://doi.org/10.1029/2008GB003243, 2009.

Beerling, D. J., Taylor, L. L., Bradshaw, C. D. C., Lunt, D. J., Valdes, P. J., Banwart, S. A., Pagani, M., and Leake, J. R.: Ecosystem $\mathrm{CO}_{2}$ starvation and terrestrial silicate weathering: mechanisms and global-scale quantification during the late Miocene, J. Ecol., 100, 31-41, 2012.

Beerling, D. J., Leake, J. R., Long, S. P., Scholes, J. D., Ton, J., Nelson, P. N., Bird, M., Kantzas, E., Taylor, L. L., Sarkar, B., Kelland, M., DeLucia, E., Kantola, I., Muller, C., Rau, G. H., and Hansen, J.: Farming with crops and rocks to address global climate, food and soil security, Nat. Plants, 4, 138-147, 2018.

Bell, E. A., Boehnke, P., Harrison, T. M., and Mao, W. L.: Potentially biogenic carbon preserved in a 4.1 billion-year-old zircon, P. Natl. Acad. Sci. USA, 112, 14518-14521, 2015.

Belyazid, S., Akselsson, C., and Zanchi, G.: Water limitation may restrict the positive effect of higher temperatures on weathering rates in forest soils, Biogeosciences Discuss., https://doi.org/10.5194/bg-2019-44, in review, 2019.

Berner, R. A.: Paleoclimate - The rise of plants and their effect on weathering and atmospheric $\mathrm{CO}_{2}$, Science, 276, 544-546, 1997. 
Blum, J. D., Klaue, A., Nezat, C. A., Driscoll, C. T., Johnson, C. E., Siccama, T. G., Eagar, C., Fahey, T. J., and Likens, G. E.: Mycorrhizal weathering of apatite as an important calcium source in base-poor forest ecosystems, Nature, 417, 729-731, 2002.

Bolou-Bi, E. B., Vigier, N., Brenot, A., and Poszwa, A.: Magnesium isotope compositions of natural reference materials, Geostand. Geoanal. Res., 33, 95-109, 2009.

Bolou-Bi, E. B., Vigier, N., Poszwa, A., Boudot, J. P., and Dambrine, E.: Effects of biogeochemical processes on magnesium isotope variations in a forested catchment in the Vosges Mountains (France), Geochim. Cosmochim. Ac., 87, 341-355, 2012.

Bonneville, S., Smits, M. M., Brown, A., Harrington, J., Leake, J. R., Brydson, R., and Benning, L. G.: Plant-driven fungal weathering: Early stages of mineral alteration at the nanometer scale, Geology, 37, 615-618, 2009.

Bonneville, S., Morgan, D. J., Schmalenberger, A., Bray, A., Brown, A., Banwart, S. A., and Benning, L. G.: Tree-mycorrhiza symbiosis accelerate mineral weathering: Evidences from nanometerscale elemental fluxes at the hypha-mineral interface, Geochim. Cosmochim. Ac., 75, 6988-7005, 2011.

Bonneville, S., Bray, A. W., and Benning, L. G.: Structural Fe(II) oxidation in biotite by an ectomycorrhizal fungi drives mechanical forcing, Environ. Sci. Technol., 50, 5589-5596, 2016.

Borgeaud, S., Metzger, L. C., Scrignari, T., and Blokesch, M.: The type VI secretion system of Vibrio cholerae fosters horizontal gene transfer, Science, 347, 63-67, 2015.

Brantley, S. L., Megonigal, J. P., Scatena, F. N., Balogh-Brunstad, Z., Barnes, R. T., Bruns, M. A., Van Cappellen, P., Dontsova, K., Hartnett, H. E., Hartshorn, A. S., Heimsath, A., Herndon, E., Jin, L., Keller, C. K., Leake, J. R., McDowell, W. H., Meinzer, F. C., Mozdzer, T. J., Petsch, S., Pett-Ridge, J., Pregitzer, K. S., Raymond, P. A., Riebe, C. S., Shumaker, K., Sutton-Grier, A., Walter, R., and Yoo, K.: Twelve testable hypotheses on the geobiology of weathering, Geobiology, 9, 140-165, 2011.

Brocks, J. J., Logan, G. A., Buick, R., and Summons, R. E.: Archean molecular fossils and the early rise of eukaryotes, Science, 285, 1033-1036, 1999.

Brown, G., Mitchell, D. T., and Stock, W. D.: Deposition of phosphorus in a coastal Fynbos ecosystem of the south-western Cape, South Africa, J. Ecol., 72, 547-551, 1984.

Cailleau, G., Braissant, O., and Verrecchia, E. P.: Turning sunlight into stone: the oxalate-carbonate pathway in a tropical tree ecosystem, Biogeosciences, 8, 1755-1767, https://doi.org/10.5194/bg-8-1755-2011, 2011.

Cailleau, G., Mota, M., Bindschedler, S., Junier, P., and Verrecchia, E. P.: Detection of active oxalate-carbonate pathway ecosystems in the Amazon Basin: Global implications of a natural potential C sink, Catena, 116, 132-141, 2014.

Callot, G., Maurette, M., Pottier, L., and Dubois, A.: Biogenic Etching of Microfractures in Amorphous and Crystalline Silicates, Nature, 328, 147-149, 1987.

Calvaruso, C., Turpault, M-. P., Frey-Klett, P., Uroz, S., Pierret, M.-C. Tosheva, Z., and Antoine, K.: Increase of apatite dissolution rate by Scots pine roots associated or not with Burkholderia glathei PML1(12)Rp in open-system flow microcosms, Geochim. Cosmochim. Ac., 106, 287-306, 2013.

Chizhikova, N. P., Lessovaia, S. N., and Gorbushina, A. A.: Biogenic Weathering of Mineral Substrates (Review), in: Biogenic-Abiogenic Interactions in Natural and Anthropogenic Systems, edited by: Frank-Kamenetskaya, O. V., Panova, E. G., and Vlasov, D. Y., Springer, Cham, 7-14, https://doi.org/10.1007/978-3-319-24987-2_2, 2016.

Clemmensen, K. E., Bahr, A., Ovaskainen, O., Dahlberg, A., Ekblad, A., Wallander, H., Stenlid, J., Finlay, R. D., Wardle, D. A., and Lindahl, B. D.: Roots and associated fungi drive long-term carbon sequestration in boreal forest, Science, 339, 1615-1618, 2013.

Cobert, F., Schmitt, A. D., Bourgeade, P., Labolle, F., Badot, P. M., Chabaux, F., and Stille, P.: Experimental identification of Ca isotopic fractionations in higher plants, Geochim. Cosmochim. Ac., 75, 5467-5482, 2011.

DasSarma, S. and Schwieterman, E. W.: Early evolution of purple retinal pigments on Earth and implications for exoplanet biosignatures, Int. J. Astrobiol., 1-10, https://doi.org/10.1017/S1473550418000423, 2018.

Deveau, A., Bonito, G., Uehling, J., Paoletti, M., Becker, M., Bindschedler, S., Hacquard, S., Herve, V., Labbe, J., Lastovetsky, O. A., Mieszkin, S., Millet, L. J., Vajna, B., Junier, P., Bonfante, P., Krom, B. P., Olsson, S., van Elsas, J. D., and Wick, L. Y.: Bacterial-fungal interactions: ecology, mechanisms and challenges, FEMS Microbiol. Rev., 42, 335-352, 2018.

Dijkstra, F. A. and Smits, M. M.: Tree species effects on calcium cycling: the role of calcium uptake in deep soils, Ecosystems, 5, 385-398, 2002.

Drever, J. I. and Stillings, L. L.: The role of organic acids in mineral weathering, Coll. Surf. A, 120, 167-181, https://doi.org/10.1016/S0927-7757(96)03720-X, 1997.

Erlandsson, M., Oelkers, E. H., Bishop, K., Sverdrup, H., Belyazid, S., Ledesma, J. L. J., and Kohler, S. J.: Spatial and temporal variations of base cation release from chemical weathering on a hillslope scale, Chem. Geol., 441, 1-13, 2016.

Fahad, Z. A., Bolou-Bi, E. B., Kohler, S. J., Finlay, R. D., and Mahmood, S.: Fractionation and assimilation of $\mathrm{Mg}$ isotopes by fungi is species dependent, Env. Microbiol. Rep., 8, 956-965, https://doi.org/10.1111/1758-2229.12459, 2016.

Ferris, F. G., Wiese, R. G., and Fyfe, W. S.: Precipitation of carbonate minerals by microorganisms - Implications for silicate weathering and the global carbon-dioxide budget, Geomicrobiol. J., 12, 1-13, 1994.

Field, K. J., Cameron, D. D., Leake, J. R., Tille, S., Bidartondo, M. I., and Beerling, D. J.: Contrasting arbuscular mycorrhizal responses of vascular and non-vascular plants to a simulated Palaeozoic $\mathrm{CO}_{2}$ decline, 3, 835, https://doi.org/10.1038/ncomms1831, 2012.

Field, K. J., Davidson, S. J., Alghamadi, S. A., and Cameron, D. D.: Magnitude, dynamics and control of carbon flow to mycorrhizas, in: Mycorrhizal Mediation of Soil Fertility, Structure, and Carbon Storage, edited by: Johnson, N. C., Gehring, C., and Jansa, J., Elsevier, Amsterdam, 375-393, ISBN 978-0-12-8043127, 2017.

Finlay, R. D. and Clemmensen, K. E.: Immobilization of carbon in mycorrhizal mycelial biomass and secretions, in: Mycorrhizal Mediation of Soil Fertility, Structure, and Carbon Storage, edited by: Johnson, N. C., Gehring, C., and Jansa, J.: Elsevier, Amsterdam, 413-440, ISBN 978-0-12-8043127, 2017.

Finlay, R. D., Wallander, H., Smits, M., Holmstrom, S., Hees, P. V., Lian, B., and Rosling, A.: The role of fungi in biogenic weathering in boreal forest soils, Fung. Biol. Rev., 4, 101-106, 2009. 
Flemming, H. C. and Wingender, J.: The biofilm matrix, Nat. Rev. Microbiol., 8, 623-633, 2010.

Flemming, H. C., Wingender, J., Szewzyk, U., Steinberg, P., Rice, S. A., and Kjelleberg, S.: Biofilms: an emergent form of bacterial life, Nat. Rev. Microbiol., 14, 563-575, 2016.

Fomina, M., Burford, E. P., Hillier, S., Kierans, M., and Gadd, G. M.: Rock-building fungi, Geomicrobiol. J., 27, 624-629, 2010.

Futter, M. N., Klaminder, J., Lucas, R. W., Laudon, H., and Kohler, S. J.: Uncertainty in silicate mineral weathering rate estimates: source partitioning and policy implications, Environ. Res. Lett., 7, 024025, https://doi.org/10.1088/1748-9326/7/2/024025, 2012.

Gadd, G. M.: Metals, minerals and microbes: geomicrobiology and bioremediation, Microbiology, 156, 609-643, 2010.

Gadd, G. M.: Microbial roles in mineral transformations and metal cycling in the Earth's critical zone, in: Molecular Environmental Soil Science. Progress in Soil Science, edited by: Xu J. and Sparks D.: Springer, Dordrecht, 115-165, ISBN 978-94-0074176-8, 2013a.

Gadd, G. M.: Geomycology: Fungi as agents of biogeochemical change, Biology and Environment, P. Roy. Irish Acad., 113b, 139-153, 2013b.

Gadd, G. M.: Fungi, rocks, and minerals, Elements, 13, 171-176, 2017.

Gazzè, S. A., Saccone, L., Ragnarsdottir, K. V., Smits, M. M., Duran, A. L., Leake, J. R., Banwart, S. A., and McMaster, T. J.: Nanoscale channels on ectomycorrhizal-colonized chlorite: Evidence for plant-driven fungal dissolution, J. Geophys. Res.Biogeo., 117, G00n09, https://doi.org/10.1029/2012JG002016, 2012.

Gazzè, S. A., Saccone, L., Smits, M. M., Duran, A. L., Leake, J. R., Banwart, S. A., Ragnarsdottir, K. V., and McMaster, T. J.: Nanoscale observations of extracellular polymeric substances deposition on phyllosilicates by an ectomycorrhizal fungus, Geomicrobiol. J., 30, 721-730, 2013.

Gazze, S. A., Stack, A. G., Ragnarsdottir, K. V., and McMaster, T. J.: Chlorite topography and dissolution of the interlayer studied with atomic force microscopy, Am. Mineral., 99, 128-138, 2014.

Gleeson, D. B., Clipson, N., Melville, K., Gadd, G. M., and McDermott, F. P.: Mineralogical control of fungal community structure in a weathered pegmatitic granite, Microb. Ecol., 50, 360-368, 2005.

Gorbushina, A. A.: Life on the rocks, Env. Microbiol., 9, 16131631, 2007.

Goudie, A. S. and Viles, H. A.: Weathering and the global carbon cycle: Geomorphological perspectives, Earth-Sci. Rev., 113, 5971, 2012.

Griffiths, R. P., Baham, J. E., and Caldwell, B. A.: Soil solution chemistry of ectomycorrhizal mats in forest soil, Soil Biol. Biochem., 26, 331-337, 1994.

Grube, M., Cernava, T., Soh, J., Fuchs, S., Aschenbrenner, I., Lassek, C., Wegner, U., Becher, D., Riedel, K., Sensen, C. W., and Berg, G.: Exploring functional contexts of symbiotic sustain within lichen-associated bacteria by comparative omics, ISME J., 9, 412-424, 2015.

Guennoc, C. M., Rose, C., Labbe, J., and Deveau, A.: Bacterial biofilm formation on the hyphae of ectomycorrhizal fungi: a widespread ability under controls?, FEMS Microbiol. Ecol., 94, fiy093, https://doi.org/10.1093/femsec/fiy093, 2018.
Hartmann, J. and Moosdorf, N.: Chemical weathering rates of silicate-dominated lithological classes and associated liberation rates of phosphorus on the Japanese Archipelago - Implications for global scale analysis, Chem. Geol., 287, 125-157, 2011.

Hazen, R. M., Papineau, D., Leeker, W. B., Downs, R. T., Ferry, J. M., McCoy, T. J., Sverjensky, D. A., and Yang, H. X.: Mineral evolution, Am. Mineral., 93, 1693-1720, 2008.

Hibbett, D., Gilbert, L., and Donoghue, M.: Evolutionary instability of ectomycorrhizal symbiosis in basidiomycetes, Nature, 407, 506-508, 2000.

Hindshaw, R. S., Reynolds, B. C., Wiederhold, J. G., Kretzschmar, R., and Bourdon, B.: Calcium isotopes in a proglacial weathering environment: Damma glacier, Switzerland, Geochim. Cosmochim. Ac., 75, 106-118, 2011.

Hodkinson, B. P., Gottel, N. R., Schadt, C. W., and Lutzoni, F.: Photoautotrophic symbiont and geography are major factors affecting highly structured and diverse bacterial communities in the lichen microbiome, Environ. Microbiol., 14, 147-161, 2012.

Hoffland, E., Giesler, R., Jongmans, T., and van Breemen, N.: Increasing feldspar tunneling by fungi across a north Sweden podzol chronosequence, Ecosystems, 5, 11-22, 2002.

Hoffland, E., Giesler, R., Jongmans, A. G., and van Breemen, N.: Feldspar tunneling by fungi along natural productivity gradients, Ecosystems, 6, 739-746, 2003.

Hoffland, E., Kuyper, T. W., Wallander, H., Plassard, C., Gorbushina, A. A., Haselwandter, K., Holmstrom, S., Landeweert, R., Lundstrom, U. S., Rosling, A., Sen, R., Smits, M. M., van Hees, P. A., and van Breemen, N.: The role of fungi in weathering, Front. Ecol. Environ., 2, 258-264, 2004.

Högberg, M. N. and Högberg, P.: Extramatrical ectomycorrhizal mycelium contributes one-third of microbial biomass and produces, together with associated roots, half the dissolved organic carbon in a forest soil, New Phytol., 154, 791-795, 2002.

Högberg, P., Nordgren, A., Buchmann, N., Taylor, A. F. S., Ekblad, A., Högberg, M. N., Nyberg, G., Ottosson-Lofvenius, M., and Read, D. J.: Large-scale forest girdling shows that current photosynthesis drives soil respiration, Nature, 411, 789-792, 2001.

Holmden, C. and Belanger, N.: Ca isotope cycling in a forested ecosystem, Geochim. Cosmochim. Ac., 74, 995-1015, 2010.

Holmstrom, S. J. M., Lundstrom, U. S., Finlay, R. D., and Van Hees, P. A. W.: Siderophores in forest soil solution, Biogeochemistry, 71, 247-258, 2004.

Howard, R. J., Ferrari, M. A., Roach, D. H., and Money, N. P.: Penetration of hard substrates by a fungus employing enormous turgor pressures, P. Natl. Acad. Sci. USA, 88, 11281-11284, 1991.

Huang, K. J., Teng, F. Z., Wei, G. J., Ma, J. L., and Bao, Z. Y.: Adsorption- and desorption-controlled magnesium isotope fractionation during extreme weathering of basalt in Hainan Island, China, Earth Planet. Sc. Lett., 359, 73-83, 2012.

Hutchens, E.: Microbial selectivity on mineral surfaces: possible implications for weathering processes, Fung. Biol. Rev., 23, 115121, 2010.

Johansson, E. M., Fransson, P. M. A., Finlay, R. D., and van Hees, P. A. W.: Quantitative analysis of soluble exudates produced by ectomycorrhizal roots as a response to ambient and elevated $\mathrm{CO}_{2}$, Soil Biol. Biochem., 41, 1111-1116, 2009.

Jones, D. L., Nguyen, C., and Finlay, R. D.: Carbon flow in the rhizosphere: carbon trading at the soil-root interface, Plant Soil, 321, 5-33, 2009. 
Jongmans, A. G., van Breemen, N., Lundstrom, U., van Hees, P. A. W., Finlay, R. D., Srinivasan, M., Unestam, T., Giesler, R., Melkerud, P. A., and Olsson, M.: Rock-eating fungi, Nature, 389, 682-683, 1997.

Kalinowski, B. E., Liermann, L. J., Brantley, S. L., Barnes, A., and Pantano, C. G.: X-ray photoelectron evidence for bacteriaenhanced dissolution of hornblende, Geochim. Cosmochim. Ac., 64, 1331-1343, 2000.

Klaminder, J., Lucas, R. W., Futter, M. N., Bishop, K. H., Kohler, S. J., Egnell, G., and Laudon, H.: Silicate mineral weathering rate estimates: Are they precise enough to be useful when predicting the recovery of nutrient pools after harvesting?, Forest Ecol. Manag., 261, 1-9, 2011.

Koele, N., Dickie, I. A., Oleksyn, J., Richardson, S. J., and Reich, P. B.: No globally consistent effect of ectomycorrhizal status on foliar traits, New Phytol., 196, 845-852, 2012.

Koele, N., Dickie, I. A., Blum, J. D., Gleason, J. D., and de Graaf, L.: Ecological significance of mineral weathering in ectomycorrhizal and arbuscular mycorrhizal ecosystems from a field-based comparison, Soil Biol. Biochem., 69, 63-70, 2014.

Kohler, A., Kuo, A., Nagy, L. G., Morin, E., Barry, K. W., Buscot, F., Canback, B., Choi, C., Cichocki, N., Clum, A., Colpaert, J., Copeland, A., Costa, M. D., Dore, J., Floudas, D., Gay, G., Girlanda, M., Henrissat, B., Herrmann, S., Hess, J., Hogberg, N., Johansson, T., Khouja, H. R., LaButti, K., Lahrmann, U., Levasseur, A., Lindquist, E. A., Lipzen, A., Marmeisse, R., Martino, E., Murat, C., Ngan, C. Y., Nehls, U., Plett, J. M., Pringle, A., Ohm, R. A., Perotto, S., Peter, M., Riley, R., Rineau, F., Ruytinx, J., Salamov, A., Shah, F., Sun, H., Tarkka, M., Tritt, A., VeneaultFourrey, C., Zuccaro, A., Tunlid, A., Grigoriev, I. V., Hibbett, D. S., Martin, F., and Mycorrhizal Genomics Initiative: Convergent losses of decay mechanisms and rapid turnover of symbiosis genes in mycorrhizal mutualists, Nat. Genet., 47, 410-415, 2015.

Kohler, P., Hartmann, J., and Wolf-Gladrow, D. A.: Geoengineering potential of artificially enhanced silicate weathering of olivine, $P$. Natl. Acad. Sci. USA, 107, 20228-20233, 2010.

Kraemer, S. M., Duckworth, O. W., Harrington, J. M., and Schenkeveld, W. D. C.: Metallophores and trace metal biogeochemistry, Aquat. Geochem., 21, 159-195, 2014.

Kronnäs, V., Akselsson, C., and Belyazid, S.: Dynamic modelling of weathering rates - the benefit over steady-state modelling, Soil, 5, 33-47, 2019.

Kump, L. R.: The rise of atmospheric oxygen, Nature, 451, 277278, 2008

Lambers, H., Raven, J. A., Shaver, G. R., and Smith, S. E.: Plant nutrient-acquisition strategies change with soil age, Trends Ecol. Evol., 23, 95-103, 2008.

Lambers, H., Mougel, C., Jaillard, B., and Hinsinger, P.: Plantmicrobe-soil interactions in the rhizosphere: an evolutionary perspective, Plant Soil, 321, 83-115, 2009.

Landeweert, R., Hofflund, E., Finlay, R. D., and van Breemen, N.: Linking plants to rocks: Ectomycorrhizal fungi mobilize nutrients from minerals, Trends Ecol. Evol., 16, 248-254, 2001.

Lawrence, C., Harden, J., and Maher, K.: Modeling the influence of organic acids on soil weathering, Geochim. Cosmochim. Ac., 139, 487-507, 2014.

Leake, J. R. and Read, D. J.: Mycorrhizal symbioses and pedogenesis throughout Earth's history, in: Mycorrhizal Mediation of Soil Fertility, Structure, and Carbon Storage, edited by: Johnson,
N. C., Gehring, C., and Jansa, J.: Elsevier, Amsterdam, 9-33, ISBN 978-0-12-8043127, 2017.

Leake, J. R., Duran, A. L., Hardy, K. E., Johnson, I., Beerling, D. J., Banwart, S. A., and Smits, M. M.: Biological weathering in soil: the role of symbiotic root-associated fungi biosensing minerals and directing photosynthate-energy into grain-scale mineral weathering, Min. Mag., 72, 85-89, 2008.

Li, Z. B., Liu, L. W., Chen, J., and Teng, H. H.: Cellular dissolution at hypha- and spore- mineral interfaces revealing unrecognized mechanisms and scales of fungal weathering, Geology, 44, 319322, 2016.

Lian, B., Wang, B., Pan, M., Liu, C. Q., and Teng, H. H.: Microbial release of potassium from $\mathrm{K}$-bearing minerals by thermophilic fungus Aspergillus fumigatus, Geochim. Cosmochim. Ac., 72, 87-98, 2008

Lian, B., Chen, Y., and Tang, Y. A.: Microbes on Carbonate Rocks and Pedogenesis in Karst Regions, J. Earth Sci.-China, 21, 293 296, 2010.

Lian, B., Yuan, D. X., and Liu, Z. H.: Effect of microbes on karstification in karst ecosystems, Chinese Sci. Bull., 56, 3743-3747, 2011.

Lindahl, B. D. and Tunlid, A.: Ectomycorrhizal fungi - potential organic matter decomposers, yet not saprotrophs, New Phytol., 205, 1443-1447, 2015.

Lindahl, B. D., Ihrmark, K., Boberg, J., Trumbore, S. E., Hogberg, P., Stenlid, J., and Finlay, R. D.: Spatial separation of litter decomposition and mycorrhizal nitrogen uptake in a boreal forest, New Phytol., 173, 611-620, 2007.

Liu, H. L. and Lian, B.: Quantitative evaluation of different fractions of extracellular polymeric substances derived from Paenibacillus mucilaginosus against the toxicity of gold ions, Coll. Surf. B, 175, 195-201, 2019.

Liu, Y. P., Sun, Q. B., Li, J., and Lian, B.: Bacterial diversity among the fruit bodies of ectomycorrhizal and saprophytic fungi and their corresponding hyphosphere soils, Sci. Rep., 8, 11672, https://doi.org/10.1038/s41598-018-30120-6, 2018.

Luo, G. M., Ono, S. H., Beukes, N. J., Wang, D. T., Xie, S. C., and Summons, R. E.: Rapid oxygenation of Earth's atmosphere 2.33 billion years ago, Sci. Adv., 2, e1600134, https://doi.org/10.1126/sciadv.1600134, 2016.

Ma, J. F., Ryan, P. R., and Delhaize, E.: Aluminium tolerance in plants and the complexing role of organic acids, Trends Plant Sci., 6, 273-278, 2001.

Maher, K.: The dependence of chemical weathering rates on fluid residence time, Earth Planet. Sc. Lett., 294, 101-110, 2010.

Martin, F., Kohler, A., Murat, C., Veneault-Fourrey, C., and Hibbett, D. S.: Unearthing the roots of ectomycorrhizal symbioses, Nat. Rev. Microbiol., 14, 760-773, 2016.

Martino, E., Perotto, S., Parsons, R., and Gadd, G. M.: Solubilization of insoluble inorganic zinc compounds by ericoid mycorrhizal fungi derived from heavy metal polluted sites, Soil Biol. Biochem., 35, 133-141, 2003.

Marupakula, S., Mahmood, S., and Finlay, R. D.: Analysis of single root tip microbiomes suggests that distinctive bacterial communities are selected by Pinus sylvestris roots colonized by different ectomycorrhizal fungi, Env. Microbiol., 18, 1470-1483, 2016.

Marupakula, S., Mahmood, S., Jernberg, J., Nallanchakravarthula, S., Fahad, Z. A., and Finlay, R. D.: Bacterial microbiomes of individual ectomycorrhizal Pinus sylvestris roots are shaped by 
soil horizon and differentially sensitive to nitrogen addition, Env. Microbiol., 19, 4736-4753, 2017.

Mavromatis, V., Prokushkin, A. S., Pokrovsky, O. S., Viers, J., and Korets, M. A.: Magnesium isotopes in permafrost-dominated Central Siberian larch forest watersheds, Geochim. Cosmochim. Ac., 147, 76-89, 2014.

McLoughlin, N., Staudigel, H., Furnes, H., Eickmann, B., and Ivarsson, M.: Mechanisms of microtunneling in rock substrates: distinguishing endolithic biosignatures from abiotic microtunnels, Geobiology, 8, 245-255, 2010.

McMaster, T. J.: Atomic Force Microscopy of the fungi-mineral interface: applications in mineral dissolution, weathering and biogeochemistry, Curr. Opin. Biotech., 23, 562-569, 2012.

Mitchell, A. C., Lafreniere, M. J., Skidmore, M. L., and Boyd, E. S.: Influence of bedrock mineral composition on microbial diversity in a subglacial environment, Geology, 41, 855-858, 2013.

Moldan, F., Stadmark, J., Fölster, J., Jutterström, S., Futter, M. N., Cosby, B. J., and Wright, R. F.: Consequences of intensive forest harvesting on the recovery of Swedish lakes from acidification and on critical load exceedances, Sci. Total Environ., 603, 562$569,2017$.

Montross, S. N., Skidmore, M., Tranter, M., Kivimaki, A. L., and Parkes, R. J.: A microbial driver of chemical weathering in glaciated systems, Geology, 41, 215-218, 2013.

Moreau, D., Bardgett, R. D., Finlay, R. D., Jones, D. L., and Philippot, L.: A plant perspective on nitrogen cycling in the rhizosphere, Funct. Ecol., 33, 540-552, 2019.

Morris, J. L., Leake, J. R., Stein, W. E., Berry, C. M., Marshall, J. E. A., Wellman, C. H., Milton, A., Hillier, S., Mannolini, F., Quirk, J., and Beerling, D. J.: Investigating Devonian trees as geoengineers of past climates: linking palaeosols to palaeobotany and experimental geobiology, Palaeontology, 58, 787-801, 2015.

Neaman, A., Chorover, J., and Brantley, S. L.: Effects of organic ligands on granite dissolution in batch experiments at $\mathrm{pH} 6$, Amer. J. Sci., 306, 451-473, 2006.

Nicolás, C., Martin-Bertelsen, T., Floudas, D., Bentzer, J., Smits, M., Johansson, T., Troein, C., Persson, P., and Tunlid, A.: The soil organic matter decomposition mechanisms in ectomycorrhizal fungi are tuned for liberating soil organic nitrogen, ISME J., 13, 977-988, 2019.

Ochs, M.: Influence of humified and non-humified natural organic compounds on mineral dissolution, Chem. Geol., 132, 119-124, 1996.

Opfergelt, S., Burton, K. W., Georg, R. B., West, A. J., Guicharnaud, R. A., Sigfusson, B., Siebert, C., Gislason, S. R., and Halliday, A. N.: Magnesium retention on the soil exchange complex controlling $\mathrm{Mg}$ isotope variations in soils, soil solutions and vegetation in volcanic soils, Iceland, Geochim. Cosmochim. Ac., 125, 110-130, 2014.

Pagani, M., Caldeira, K., Berner, R., and Beerling, D. J.: The role of terrestrial plants in limiting atmospheric $\mathrm{CO}_{2}$ decline over the past 24 million years, Nature, 460, 85-94, 2009.

Page, B. D., Bullen, T. D., and Mitchell, M. J.: Influences of calcium availability and tree species on $\mathrm{Ca}$ isotope fractionation in soil and vegetation, Biogeochemistry, 88, 1-13, 2008.

Paris, F., Bonnaud, P., Ranger, J., and Lapeyrie F.: In vitro weathering of phlogopite by ectomycorrhizal fungi. I. Effect of $\mathrm{K}^{+}$ and $\mathrm{Mg}^{2+}$ deficiency on phyllosilicate evolution, Plant Soil, 177, 191-201, 1995.
Paris, F., Botton, B., and Lapeyrie, F.: In vitro weathering of phlogopite by ectomycorrhizal fungi. 2. Effect of $\mathrm{K}^{+}$and $\mathrm{Mg}^{2+}$ deficiency and $\mathrm{N}$ sources on accumulation of oxalate and $\mathrm{H}^{+}$, Plant Soil, 179, 141-50, 1996.

Perakis, S. S. and Pett-Ridge, J. C.: Nitrogen-fixing red alder trees tap rock-derived nutrients, P. Natl. Acad. Sci. USA, 116, 50095014, 2019.

Phelan, J., Belyazid, S., Kurz, D., Guthrie, S., Cajka, J., Sverdrup, H., and Waite, R.: Estimation of soil base cation weathering rates with the PROFILE model to determine critical loads of acidity for forested ecosystems in Pennsylvania, USA: Pilot application of a potential national methodology, Water Air Soil Poll., 225, 2109, https://doi.org/10.1007/s11270-014-2109-4, 2014.

Philippot, L., Raaijmakers, J. M., Lemanceau, P., and van der Putten, W. H.: Going back to the roots: the microbial ecology of the rhizosphere, Nat. Rev. Microbiol., 11, 789-799, 2013.

Pogge von Strandmann, P. A. E., Burton, K. W., James, R. H., van Calsteren, P., Gislason, S. R., and Sigfusson, B.: The influence of weathering processes on riverine magnesium isotopes in a basaltic terrain, Earth Planet. Sc. Lett., 276, 187-197, 2008.

Povak, N. A., Hessburg, P. F., McDonnell, T. C., Reynolds, K. M., Sullivan, T. J., Salter, R. B., and Cosby, B. J.: Machine learning and linear regression models to predict catchment-level base cation weathering rates across the southern Appalachian Mountain region, USA, Water Resour. Res., 50, 2798-2814, 2014.

Price, J. R., Peresolak, K., Brice, R. L., and Tefend, K. S.: Temporal variability in the chemical weathering of $\mathrm{Ca}^{2+}$-bearing phases in the Loch Vale watershed, Colorado, USA: A mass-balance approach, Chem. Geol., 342, 151-166, 2013.

Querejeta, J. I., Egerton-Warburton, L. M., and Allen, M. F.: Direct nocturnal water transfer from oaks to their mycorrhizal symbionts during severe soil drying, Oecologia, 134, 55-64, 2003.

Quirk, J., Beerling, D. J., Banwart, S. A., Kakonyi, G., RomeroGonzalez, M. E., and Leake, J. R.: Evolution of trees and mycorrhizal fungi intensifies silicate mineral weathering, Biol. Lett., 8 , 1006-1011, 2012.

Quirk, J., Andrews, M. Y., Leake, J. R., Banwart, S. A., and Beerling, D. J.: Ectomycorrhizal fungi and past high $\mathrm{CO}_{2}$ atmospheres enhance mineral weathering through increased below-ground carbon-energy fluxes, Biol. Lett., 10, 20140375, https://doi.org/10.1098/rsbl.2014.0375, 2014a.

Quirk, J., Leake, J. R., Banwart, S. A., Taylor, L. L., and Beerling, D. J.: Weathering by tree-root-associating fungi diminishes under simulated Cenozoic atmospheric $\mathrm{CO} 2$ decline, Biogeosciences, 11, 321-331, https://doi.org/10.5194/bg-11-321-2014, 2014 b.

Quirk, J., Leake, J. R., Johnson, D. A., Taylor, L. L., Saccone, L., and Beerling, D. J.: Constraining the role of early land plants in Palaeozoic weathering and global cooling, P. Roy. Soc. B, 282, 20151115, https://doi.org/10.1098/rspb.2015.1115, 2015.

Redfield, G. W.: Atmospheric deposition of phosphorus to the everglades: concepts, constraints and published deposition rates for ecosystem management, Sci. World J., 2, 1843-1873, 2002.

Reichard, P. U., Kraemer, S. M., Frazier, S. W., and Kretzschmar, R.: Goethite dissolution in the presence of phytosiderophores: Rates, mechanisms, and the synergistic effect of oxalate, Plant Soil, 276, 115-132, 2005.

Remiszewski, K. A., Bryce, J. G., Fahnestock, M. F, Pettitt, E. A., Blichert-Toft, J., Vadeboncoeur, M. A., and Bailey, S. W.: Elemental and isotopic perspectives on the impact of arbuscular 
mycorrhizal and ectomycorrhizal fungi on mineral weathering across imposed geologic gradients, Chem. Geol., 445, 164-171, 2016.

Retallack, G. J.: Early forest soils and their role in Devonian global change, Science, 276, 583-585, 1997.

Roelandt, C., Goddéris, Y., and Bonnet, M.: Coupled modeling of biospheric and chemical weathering processes at the continental scale, Global Biogeochem. Cy., 24, GB2004, https://doi.org/10.1029/2008GB003420, 2010.

Rosenstock, N. P., Berner, C., Smits, M. M., Kram, P., and Wallander, H.: The role of phosphorus, magnesium and potassium availability in soil fungal exploration of mineral nutrient sources in Norway spruce forests, New Phytol., 211, 542-553, 2016.

Rosling, A., Lindahl, B. D., and Finlay, R. D.: Carbon allocation to ectomycorrhizal roots and mycelium colonising different mineral substrates, New Phytol., 162, 795-802, 2004.

Rosling, A., Roose, T., Herrmann, A. M., Davidson, F. A., Finlay, R. D., and Gadd, G. M.: Approaches to modelling mineral weathering by fungi, Fung. Biol. Rev., 23, 138-144, 2009.

Ryan, M. H., Tibbett, M., Edmonds-Tibbett, T., Suriyagoda, L. D. B., Lambers, H., Cawthray, G. R., and Pang, J.: Carbon trading for phosphorus gain: the balance between rhizosphere carboxylates and arbuscular mycorrhizal symbiosis in plant phosphorus acquisition, Plant Cell Environ., 35, 2170-2180, 2012.

Ryu, J. S., Jacobson, A. D., Holmden, C., Lundstrom, C., and Zhang, Z. F.: The major ion, delta Ca-44/40, delta Ca-44/42, and delta Mg-26/24 geochemistry of granite weathering at $\mathrm{pH}=1$ and $\mathrm{T}=25$ degrees $\mathrm{C}$ : power-law processes and the relative reactivity of minerals, Geochim. Cosmochim. Ac., 75, 6004-6026, 2011.

Saccone, L., Gazze, S. A., Duran, A. L., Leake, J. R., Banwart, S. A., Ragnarsdottir, K. V., Smits, M. M., and McMaster, T. J.: High resolution characterization of ectomycorrhizal fungal-mineral interactions in axenic microcosm experiments, Biogeochemistry, 111, 411-425, 2012.

Savage, V. J., Chopra, I., and O’Neill, A. J.: Staphylococcus aureus biofilms promote horizontal transfer of antibiotic resistance, Antimicrob. Agents Ch., 57, 1968-1970, 2013.

Schmalenberger, A., Duran, A. L., Bray, A. W., Bridge, J., Bonneville, S., Benning, L. G., Romero-Gonzalez, M. E., Leake, J. R., and Banwart, S. A.: Oxalate secretion by ectomycorrhizal Paxillus involutus is mineral-specific and controls calcium weathering from minerals, Sci. Rep., 5, 12187, https://doi.org/10.1038/srep12187, 2015.

Seiffert, F., Bandow, N., Bouehez, J., von Blanekenburg, F., and Gorbushina, A. A.: Microbial colonization of bare rocks: laboratory biofilm enhances mineral weathering, Proced. Earth Plan. Sc., 10, 123-129, 2014.

Shen, B., Jacobsen, B., Lee, C. T. A., Yin, Q. Z., and Morton, D. M.: The $\mathrm{Mg}$ isotopic systematics of granitoids in continental arcs and implications for the role of chemical weathering in crust formation, P. Natl. Acad. Sci. USA, 106, 20652-20657, 2009.

Sigurbjornsdottir, M. A., Andresson, O. S., and Vilhelmsson, O.: Analysis of the Peltigera membranacea metagenome indicates that lichen-associated bacteria are involved in phosphate solubilization, Microbiol.-SGM, 161, 989-996, 2015.

Simonsson, M., Bergholm, J., Olsson, B., von Brömssen, C., and Öborn, I.: Estimating weathering rates using base cation budgets in a Norway spruce stand on podzolised soil: Analysis of fluxes and uncertainties, Forest Ecol. Manag., 340, 135-152, 2015.

Smith, S. E. and Read, D. J.: Mycorrhizal Symbiosis, 3rd ed., Academic Press, Amsterdam, London, 2008.

Smits, M. M.: Scale matters? Exploring the effect of scale on fungal-mineral interactions, Fung. Biol. Rev., 23, 132-137, 2009.

Smits, M. M. and Wallander, H.: Role of mycorrhizal symbiosis in mineral weathering and nutrient mining from soil parent material, in: Mycorrhizal Mediation of Soil Fertility, Structure, and Carbon Storage, edited by: Johnson, N. C., Gehring, C., and Jansa, J., Elsevier, Amsterdam, 35-46, ISBN 978-0-12-8043127, 2017.

Smits, M. M., Hoffland, E., Jongmans, A. G., and van Breemen, N.: Contribution of mineral tunneling to total feldspar weathering, Geoderma, 125, 59-69, 2005.

Smits, M. M., Bonneville, S., Haward, S., and Leake, J. R.: Ectomycorrhizal weathering, a matter of scale?, Mineral. Mag., 72, 131-134, 2008.

Smits, M. M., Bonneville, S., Benning, L. G., Banwart, S. A., and Leake, J. R.: Plant-driven weathering of apatite - the role of an ectomycorrhizal fungus, Geobiology, 10, 445-456, 2012.

Smits, M. M., Johansson, L., and Wallander, H.: Soil fungi appear to have a retarding rather than a stimulating role on soil apatite weathering, Plant Soil., 385, 217-228, 2014.

Söderström, B. E.: Seasonal fluctuations of active fungal biomass in horizons of a podzolized pine-forest soil in central Sweden, Soil Biol. Biochem., 11, 149-154, 1979.

Sokolova, T. A., Tolpeshta, I. I., and Topunova, I. V.: Biotite weathering in podzolic soil under conditions of a model field experiment, Euras. Soil Sci., 43, 1150-1158, 2010.

Stendahl, J., Akselsson, C., Melkerud, P. A., and Belyazid, S.: Pedon-scale silicate weathering: comparison of the PROFILE model and the depletion method at 16 forest sites in Sweden, Geoderma, 211, 65-74, 2013.

Sterkenburg, E., Clemmensen, K. E., Ekblad, A., Finlay, R. D., and Lindahl, B. D.: Contrasting effects of ectomycorrhizal fungi on early and late stage decomposition in a boreal forest, ISME J., 12, 2187-2197, 2018.

Sun, Q., Li, J., Finlay, R. D., and Lian, B.: Oxalotrophic bacteria assemblages in the ectomycorrhizosphere and their effects on oxalate degradation and carbon fixation potential, Chem. Geol., 514, 54-65, 2019a.

Sun, Q., Ziyu, F., Finlay, R. D., and Lian, B.: Transcriptome analysis provides novel insights into the response of the ectomycorrhizal fungus Amanita pantherina to weather K-containing feldspar and apatite, Appl. Environ. Microb., 85, e00719-19, https://doi.org/10.1128/AEM.00719-19, 2019b.

Sun, Q. B. and Lian, B.: The different roles of Aspergillus nidulans carbonic anhydrases in wollastonite weathering accompanied by carbonation, Geochim. Cosmochim. Ac., 244, 437-450, 2019.

Sun, Y. P., Unestam, T., Lucas, S. D., Johanson, K. J., Kenne, L., and Finlay, R.: Exudation-reabsorption in a mycorrhizal fungus, the dynamic interface for interaction with soil and soil microorganisms, Mycorrhiza, 9, 137-144, 1999.

Sverdrup, H.: Chemical weathering of soil minerals and the role of biological processes, Fung. Biol. Rev., 23, 94-100, 2009.

Taylor, L., Banwart, S., Leake, J., and Beerling, D. J.: Modeling the evolutionary rise of ectomycorrhiza on sub-surface weather- 
ing environments and the geochemical carbon cycle, Am. J. Sci., 311, 369-403, 2011.

Taylor, L. L., Banwart, S. A., Valdes, P. J., Leake, J. R., and Beerling, D. J.: Evaluating the effects of terrestrial ecosystems, climate and carbon dioxide on weathering over geological time: a global-scale process-based approach, Philos. T. R. Soc. B, 367, 565-582, 2012.

Taylor, L. L., Quirk, J., Thorley, R. M. S., Kharecha, P. A., Hansen, J., Ridgwell, A., Lomas, M. R., Banwart, S. A., and Beerling, D. J.: Enhanced weathering strategies for stabilizing climate and averting ocean acidification, Nat. Clim. Change, 6, 402-406, 2016.

Thorley, R. M. S., Taylor, L. L., Banwart, S. A., Leake, J. R., and Beerling, D. J.: The role of forest trees and their mycorrhizal fungi in carbonate rock weathering and its significance for global carbon cycling, Plant Cell Environ., 38, 1947-1961, 2015.

Tipper, E. T., Gaillardet, J., Louvat, P., Capmas, F., and White, A. F.: Mg isotope constraints on soil pore-fluid chemistry: Evidence from Santa Cruz, California, Geochim. Cosmochim. Ac., 74, 3883-3896, 2010.

Toljander, J., Lindahl, B., Paul, L., Elfstrand, M., and Finlay, R. D..: Influence of arbuscular mycorrhizal mycelial exudates on soil bacterial growth and community structure, FEMS Microbiol. Ecol., 61, 295-304, 2007.

Tuason, M. M. S. and Arocena, J. M.: Calcium oxalate biomineralization by Piloderma fallax in response to various levels of calcium and phosphorus, Appl. Environ. Microb., 75, 7079-7085, 2009.

Turpault, M.-P., Nys, C., and Calvaruso, C.: Rhizosphere impact on the dissolution of test minerals in a forest ecosystem, Geoderma, 153, 147-154, 2009.

Uhlig, D., Schuessler, J. A., Bouchez, J., Dixon, J. L., and von Blanckenburg, F.: Quantifying nutrient uptake as driver of rock weathering in forest ecosystems by magnesium stable isotopes, Biogeosciences, 14, 3111-3128, https://doi.org/10.5194/bg-143111-2017, 2017.

Uroz, S., Oger, P., Lepleux, C., Collignon, C., Frey-Klett, P., and Turpault, M. P.: Bacterial weathering and its contribution to nutrient cycling in temperate forest ecosystems, Res. Microbiol., 162, 820-831, 2011.

Uroz, S., Turpault, M. P., Delaruelle, C., Mareschal, L., Pierrat, J. C., and Frey-Klett, P.: Minerals affect the specific diversity of forest soil bacterial communities, Geomicrobiol. J., 29, 88-98, 2012.

Uroz, S., Kelly, L. C., Turpault, M. P., Lepleux, C., and Frey-Klett, P.: The mineralosphere concept: Mineralogical control of the distribution and function of mineral-associated bacterial communities, Trends Microbiol., 23, 751-762, 2015.

Vaario, L. M., Pennanen, T., Lu, J. R., Palmen, J., Stenman, J., Leveinen, J., Kilpelainen, P., and Kitunen, V.: Tricholoma matsutake can absorb and accumulate trace elements directly from rock fragments in the shiro, Mycorrhiza, 25, 325-334, 2015.

van Breemen, N., Finlay, R., Lundstrom, U., Jongmans, A. G., Giesler, R., and Olsson, M.: Mycorrhizal weathering: A true case of mineral plant nutrition?, Biogeochemistry, 49, 53-67, 2000.

Vandenkoornhuyse, P., Quaiser, A., Duhamel, M., Le Van, A., and Dufresne, A.: The importance of the microbiome of the plant holobiont, New Phytol., 206, 1196-1206, 2015. van der Heijden, G., Bel, J., Craig, C. A., Midwood, A. J., Mareschal, L., Ranger, J., Dambrine, E., and Legout, A.: Measuring plant-available $\mathrm{Mg}, \mathrm{Ca}$, and $\mathrm{K}$ pools in the soil-an isotopic dilution assay, ACS Earth Space Chem., 2, 292-313, 2018.

van Hees, P. A. W., Vinogradoff, S. I., Edwards, A. C., Godbold, D. L., and Jones, D. L.: Low molecular weight organic acid adsorption in forest soils: effects on soil solution concentrations and biodegradation rates, Soil Biol. Biochem., 35, 1015-1026, 2003. van Hees, P. A. W., Jones, D. L., Finlay, R., Godbold, D. L., and Lundström, U. S.: The carbon we do not see - the impact of low molecular weight compounds on carbon dynamics and respiration in forest soils: a review, Soil Biol. Biochem., 37, 1-13, 2005.

van Hees, P. A. W., Rosling, A., Essen, S., Godbold, D. L., Jones, D. L., and Finlay, R. D.: Oxalate and ferricrocin exudation by the extramatrical mycelium of an ectomycorrhizal fungus in symbiosis with Pinus sylvestris, New Phytol., 169, 367-377, 2006.

van Schöll, L., Hoffland, E., and van Breemen, N.: Organic anion exudation by ectomycorrhizal fungi and Pinus sylvestris in response to nutrient deficiencies, New Phytol., 170, 153-163, $2006 a$.

van Schöll, L., Smits, M. M., and Hoffland, E.: Ectomycorrhizal weathering of the soil minerals muscovite and hornblende, New Phytol., 171, 805-814, 2006b.

Verrecchia, E. P, Braissant, O., and Cailleau, G.: The oxalatecarbonate pathway in soil carbon storage: the role of fungi and oxalotrophic bacteria, in: Fungi in Biogeochemical Cycles, edited by: Gadd, G. M., Cambridge University Press, Cambridge, 289-310, 2006.

Wallander, H., Johansson, L., and Pallon, J.: PIXE analysis to estimate the elemental composition of ectomycorrhizal rhizomorphs grown in contact with different minerals in forest soil, FEMS Microbiol. Ecol., 39, 147-156, 2002.

Wallander, H., Hagerberg, D., and Aberg, G.: Uptake of Sr-87 from microcline and biotite by ectomycorrhizal fungi in a Norway spruce forest, Soil Biol. Biochem., 38, 2487-2490, 2006.

Wang, W. Y., Lian, B., and Pan, L.: An RNA-sequencing study of the genes and metabolic pathways involved in Aspergillus niger weathering of potassium feldspar, Geomicrobiol. J., 32, 689700, 2015.

Watmough, S. A. and Dillon, P. J.: Mycorrhizal weathering in basepoor forests, Nature, 423, 823-824, 2003.

Wilcke, W., Velescu, A., Leimer, S., Bigalke, M., Boy, J., and Valarezo, C.: Biological versus geochemical control and environmental change drivers of the base metal budgets of a tropical montane forest in Ecuador during 15 years, Biogeochemistry, 136, 167-189, 2017.

Wild, B., Imfeld, G., Guyot, F., and Daval, D.: Early stages of bacterial community adaptation to silicate aging, Geology, 46, 555558, 2018.

Wild, B., Daval, D., Beaulieu, E., Pierret, M.-C., Viville, D., and Imfeld, G.: In-situ dissolution rates of silicate minerals and associated bacterial communities in the critical zone (Strengbach catchment, France), Geochim. Cosmochim. Ac., 249, 95-120, 2019.

Wimpenny, J., Gislason, S. R., James, R. H., Gannoun, A., Pogge Von Strandmann, P. A. E., and Burton, K. W.: The behaviour of $\mathrm{Li}$ and $\mathrm{Mg}$ isotopes during primary phase dissolution and sec- 
ondary mineral formation in basalt, Geochim. Cosmochim. Ac., 74, 5259-5279, 2010.

Winnick, M. J. and Maher, K.: Relationships between $\mathrm{CO}_{2}$, thermodynamic limits on silicate weathering, and the strength of the silicate weathering feedback, Earth Planet. Sc. Lett., 485, 111120,2018

Xiao, B., Lian, B., Sun, L. L., and Shao, W. L.: Gene transcription response to weathering of K-bearing minerals by Aspergillus fumigatus, Chem. Geol., 306-307, 1-9, https://doi.org/10.1080/01490451.2014.884195, 2012.

Xiao, L. L., Hao, J. C, Wang, W. Y., Lian, B., Shang, G. D., Yang, Y. W, Liu, C. Q., and Wang, S. J.: The up-regulation of carbonic anhydrase genes of Bacillus mucilaginosus under soluble $\mathrm{Ca}^{2+}$ deficiency and the heterologously expressed enzyme promotes calcite dissolution, Geomicrobiol. J., 31, 632-641, 2014.

Xiao, L. L., Lian, B., Hao, J. C., Liu, C. Q., and Wang, S. J.: Effect of carbonic anhydrase on silicate weathering and carbonate formation at present day $\mathrm{CO}_{2}$ concentrations compared to primordial values, Sci. Rep., 5, 7733, https://doi.org/10.1038/srep07733, 2015.
Xiao, L. L., Sun, Q. B., Yuan, H. T., and Lian, B.: A practical soil management to improve soil quality by applying mineral organic fertilizer, Acta Geochim., 36, 198-204, 2017.

Zetterberg, T., Olsson, B.A., Löfgren, S., Hyvönen, R., and Brandtberg, P. O.: Long-term soil calcium depletion after conventional and whole-tree harvest, Forest Ecol. Manag., 369, 102-115, 2016.

Zhang, L., Fan, J., Ding, X., He, X., Zhang, F., and Feng, G.: Hyphosphere interactions between an arbuscular mycorrhizal fungus and a phosphate solubilizing bacterium promote phytate mineralization in soil, Soil Biol. Biochem., 74, 177-183, 2014.

Zhang, L., Xu, M., Liu, Y., Zhang, F., Hodge, A., and Feng. G.: Carbon and phosphorus exchange may enable cooperation between an arbuscular mycorrhizal fungus and a phosphate-solubilizing bacterium, New Phytol., 210, 1022-1032, 2016.

Zimorski, V., Ku, C., Martin, W. F., and Gould, S.B.: Endosymbiotic theory for organelle origins, Curr. Opin. Microbiol., 22, 38-48, 2014. 